Article

\title{
From EU Directives to Local Stormwater Discharge Permits: A Study of Regulatory Uncertainty and Practice Gaps in Denmark
}

\author{
Ditte M. R. Jensen ${ }^{1, *(\mathbb{D}, \text { Anja T. H. Thomsen }}{ }^{2}$, Torben Larsen ${ }^{3}$, Sara Egemose ${ }^{4}(\mathbb{C}$ \\ and Peter S. Mikkelsen ${ }^{1}$ (D) \\ 1 Department of Environmental Engineering, DTU, Technical University of Denmark, \\ Bygningstorvet bygn. 115, 2800 Kgs. Lyngby, Denmark; psmi@env.dtu.dk \\ 2 Orbicon, Jens Juuls Vej 18, 8260 Viby J, Denmark; anja@orbicon.dk \\ 3 Department of the Build Environment, Aalborg University, Thomas Manns Vej 23, 9220 Aalborg, Denmark; \\ tlar@build.aau.dk \\ 4 Department of Biology, University of Southern Denmark, Campusvej 55, 5230 Odense M, Denmark; \\ saege@biology.sdu.dk \\ * Correspondence: dije@env.dtu.dk; Tel.: +45-4525-1439
}

Received: 1 July 2020; Accepted: 31 July 2020; Published: 5 August 2020

check for updates

\begin{abstract}
Climate changes and urbanization push cities to redesign their drainage systems, which may increase separate stormwater discharges to local recipients. In the EU, regulation of these is governed by the Water Framework Directive (WFD) and the Floods Directive, but national implementation varies and is often supplemented with local non-legislative guidelines. By reviewing trends and discrepancies in the Danish regulation practice for separated stormwater discharges, this article investigates how the directives are put into effect. A legislative gap for separate stormwater discharges introduces uncertainty in the discharge permit conditions, which especially affect conditions targeting water quality. We point to several topics to be addressed, e.g., the level at which the regulation of separate stormwater discharges takes place, opportunities for coordination with flood risk and climate change adaptation initiatives, as well as uncertainties regarding the application of Best Available Techniques. Working with these issues would elevate the regulation practice and aid regulators in reaching a more holistic and consistent approach, thus improving chances of reaching the desired recipient status before or after the WFD deadline in 2027. This could be undertaken at river basin, river basin district or national level, but there is also potential for harvesting mutual benefits by addressing these challenges internationally.
\end{abstract}

Keywords: stormwater management; water framework directive (WFD); floods directive (FD); top-down and bottom-up implementation; polycentric regulation; coordination of measures; urban drainage; natural recipients; water quality

\section{Introduction}

Initiatives to mitigate urban flood risk often affect the local recipients in terms of changed runoff patterns and reduced water quality, occasionally referred to as the "urban stream syndrome" [1]. In order to protect the natural water systems from unwanted effects of stormwater discharges, while at the same time ensuring the efficient drainage of urban areas, it is necessary to implement technical solutions that can balance these, sometimes competing, agendas (Figure 1). 


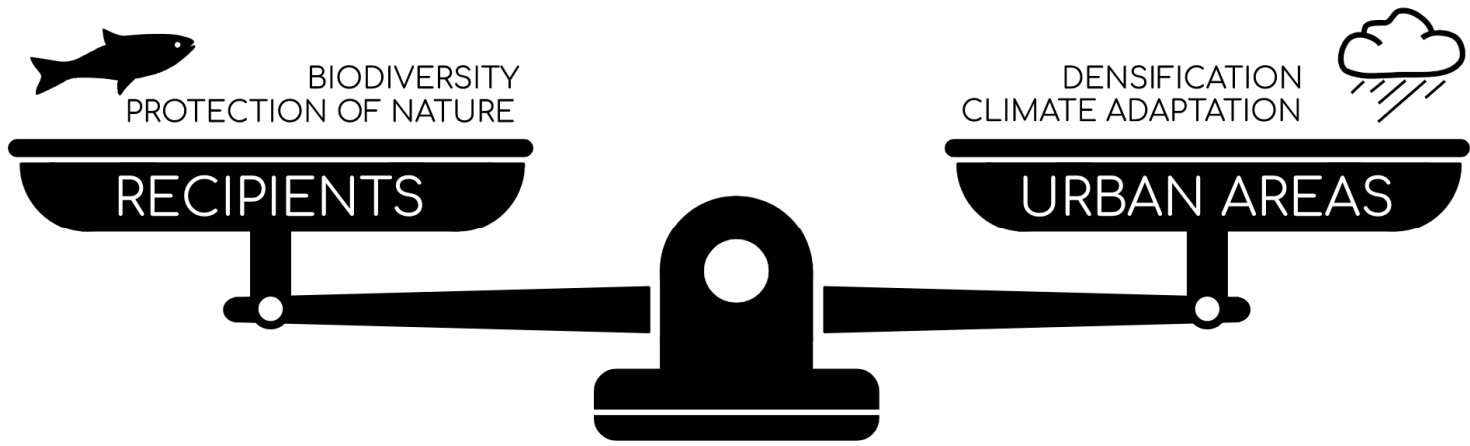

Figure 1. Illustration of the balancing act between accommodating the need for protecting the receiving natural waters and the need for effective management of stormwater in urban areas.

Worldwide, increasing urbanization [2] and land use changes negatively impact the nearby natural waters that receive the stormwater discharges [3-5]. The European Union at large has experienced a steady increase in built-up area and urban residing populations, as illustrated in Figure 2. Denmark has followed the same urbanization path over the last century, albeit at a higher level, and over the same period of time, $95 \%$ of all streams have been manipulated through, e.g., straightening, deepening, widening and piping $[3,6,7]$. Adding to these intentional physical changes to the natural recipients, the land use change that occurs when a city is built up with more impervious surfaces also reduces the natural stormwater infiltration rates of the catchments and increases the runoff peak flow and volume [1]. As stormwater dominates the flow in many small urban streams [8], the direct discharge of runoff without detention may lead to bank and bed erosion in the recipients [3]. These effects are exacerbated by climate changes [9] which increase the frequency of extreme rain events [10] and cause larger runoff peaks and volumes, which the impervious surfaces cannot alleviate.

Built-up area

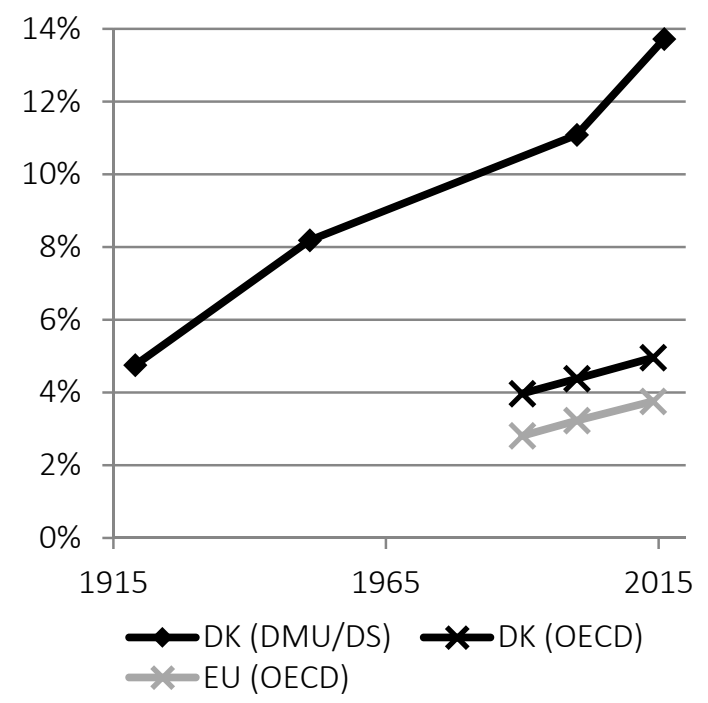

Urban residing population

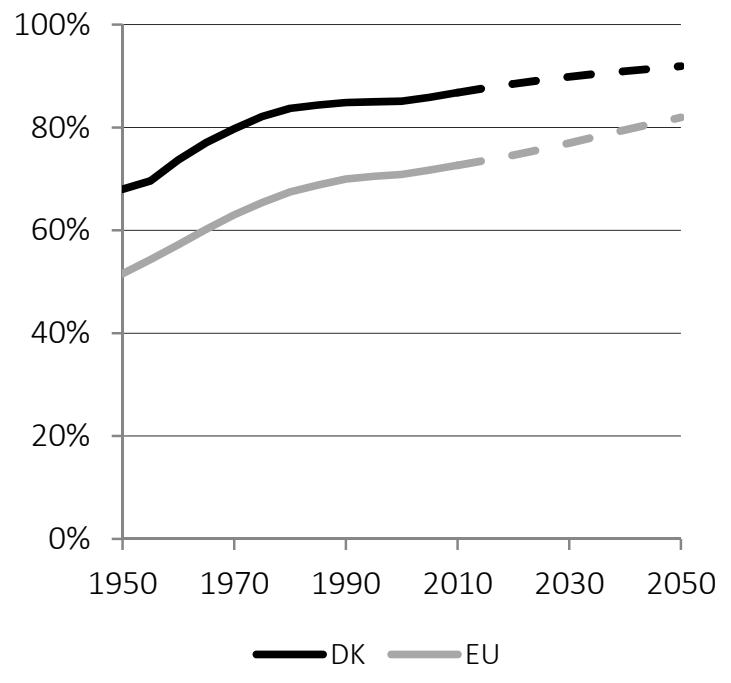

Figure 2. (Left) Percentage of total land area that has been built up using both domestic numbers from the former National Environmental Research Institute of Denmark (DMU) and Statistics Denmark (DS) [11-13] and international numbers from the Organisation for Economic Co-operation and Development (OECD) [14]. The difference in magnitude between the DMU/DS and the OECD datasets is because OECD numbers are based on all "roofed structures" (buildings), whereas the DMU/DS numbers include all registered paved surfaces. (Right) Percentage of population residing in urban areas with future projections using numbers from the United Nations [2]. 
In addition to the enhanced hydraulic load associated with changed runoff patterns, stormwater runoff from urban surfaces may also contain a broad spectrum of pollutants, such as nutrients $(\mathrm{N}$ and P), metals, polycyclic aromatic hydrocarbons (PAHs), pesticides, etc. $[8,15]$. These pollutants stem from dry and wet atmospheric deposition, the weathering of surfaces, vehicular activity and the use of specific chemicals, i.e., pesticides, spills, etc. [15-17], and are picked up by the runoff through wash-off processes. The resulting stormwater composition may thus affect the water quality of otherwise healthy freshwater ecosystems in the near-urban environments $[8,18,19]$, and can have adverse hazardous effects on both aquatic and terrestrial flora and fauna $[4,8,15,17]$.

To accommodate the pressure induced by urbanization and climate changes, cities are forced to make large investments in expansions of their drainage systems. The conventional drainage strategy in many European countries has largely relied on combined sewer systems [20], which convey both wastewater and stormwater to a central, downstream Wastewater Treatment Plant (WWTP). As it is costly to expand these systems to ensure sufficient capacity, both of the pipe network and the treatment plant [21], an alternative approach is to install separate systems. These have a separate string for urban stormwater runoff, and can lead it directly to the closest natural water system, thereby bypassing the WWTP, and thus potentially impacting the recipient with regard to both water quantity and quality issues [22], as explained above. In fact, studies have shown that, while separate systems might be superior to combined systems in terms of, e.g., nutrient loads, they are inferior when it comes to parameters such as heavy metals and COD [23]. For certain rainfall-mobilized substances, separate stormwater outlets may even have a greater effect in the recipients than overflows from combined sewers [24].

There are multiple scales at which initiatives for mitigating the impacts of the separated stormwater discharges can take place, e.g., regulation through environmental legislation, improvements through the use of technological solutions or source control through social awareness [3]. Technology wise, "end-of-pipe" strategies have been adopted as the main mitigation approach, where a central stormwater control measure (SCM), such as a detention pond, is implemented at the sub-catchment scale right before the discharge point to the natural water system $[1,18]$. In recent years, it has become popular to supplement with decentralized SCMs, such as rain gardens, bioswales, permeable pavements and green roofs [25]. These can be installed throughout the catchment, or may also be used in combination with a central, end-of-pipe SCM. Common to all the SCMs is that they may target issues regarding peak flow, pollutant emissions [19], or both, by: detaining stormwater (to alleviate peak flows and allow for the settling of particles); retaining stormwater (e.g., for irrigation, infiltration or evaporation); or treating stormwater (e.g., using filter soil or oil separators). These many different design options make it paramount to ensure the right fit given the runoff characteristics and the recipient conditions, and this is where regulatory practices become very interesting.

In Europe, there are two main directives which influence regulatory practices for stormwater management: the Water Framework Directive (WFD) [26], which aims at protecting all water systems and ensuring that they have a good ecological and chemical status and the Floods Directive (FD) [27], which presents a framework for working toward the prevention of damaging floods. A central part of the WFD implementation is the production of River Basin Management Plans (RBMPs) that describe the current status in the water environment and objectives for the future and is presented alongside a "Programme of Measures" (PoM) to be taken. Simultaneously, the implementation of the FD includes the production of Flood Risk Management Plans (FRMPs) for mitigating flood risks from rivers and coastal areas, and both the RBMPs and the FRMPs should be "climate-proofed" and coordinated with the national strategy for climate change adaptation [28]. The latest assessment reports on progress in the member states found that only $40 \%$ of European surface waters have achieved the label of good ecological status or potential, while the number is $38 \%$ for good chemical status, with some uncertainty on the actual numbers due to different reporting principles across member states [29]. The introduction of the WFD in 2000 has generally increased the focus on protecting natural recipients, but very different legislative and organizational paths are being employed across member states to 
implement the directive [30,31]. In addition to the implementation differences, many countries have introduced their own local guidelines for best practice of stormwater management to aid both water authorities and developers [19]. These are often produced by a mixture of central and regional agencies, and have not been formally adopted into the legislation [30]. A better understanding of the stormwater management issues faced by the individual countries in the EU could prevent other countries from repeating mistakes and thus increase the implementation pace of new legislation and management methods [30]. One of the obstacles in this regard is often the language barrier, which complicates international knowledge sharing.

While Denmark had a very ambitious start, its WFD implementation process has since slowed down and taken a more cost-effective focus, which also accommodates agricultural interests [32]. It is estimated that only $24 \%$ of rivers currently fulfil the WFD requirement of good ecological status [33], and with only one final round of RBMPs left to implement the WFD goals, there is a need for expediting efforts. Regarding pressures from stormwater discharges, $64 \%$ of urban catchment areas in Denmark rely on separated stormwater systems, counting a total of 15,176 known stormwater discharge points to local surface waters, of which only $25 \%$ have some kind of detention volume before discharge [34]. The discharge and treatment of stormwater locally is regulated by the municipal discharge permits, which can be used to put forth requirements targeted at the SCM design or the discharge volume and composition in order to ensure that the recipient status will comply with the set environmental objectives.

This article presents a study of the Danish regulatory practice for managing stormwater discharges here at the brink of the third and final planning cycle of the WFD. The focus is on discharges to freshwater recipients. Two reviews are performed: one of the legislative framework for stormwater regulation resulting from the implementation of the EU directives and one on the application of this framework by looking at trends and discrepancies in a series of discharge permits issued between 2014 and 2018. Our aim is to point out how gaps in the central water policy framework link to practice discrepancies among local water authorities and thus impact the level of protection received by the recipients. By covering the regulatory arena from the central formulation of practice to the local implementation of practice, we can discuss possibilities for improvements at municipal, river basin, district and national levels alike, which makes this work relevant to local practitioners, national regulators and legislators, as well as international policy makers.

\section{Materials and Methods}

\subsection{Review of Regulatory Practice}

A literature review was performed to follow the implementation paths of the WFD and FD in Denmark and to map the interface between these and the use of discharge permits. As the governing legislation for issuing discharge permits concerns the WFD, the review had its primary focus here. Apart from the respective directives, the review focused on:

- Reports from the European Union and the European Commission on the implementation of and coordination between the directives [20,28,29,35-39].

- Relevant Danish legislation (acts, consolidation acts and statutory orders) [40-51].

- Other ministerial publications (management plans, guidelines, work programs, tool catalogues, reports, analyses, etc.) [52-70].

- Key literature on the implementation of the directives and stormwater regulation at international [19,31,32,71-76] and national levels [77].

- Guidelines and reports published by central actors [78-83].

- Guidelines or other documents referenced in the reviewed discharge permits or in the other guidelines [84-88]. 


\subsection{Review of Discharge Permits}

A review was performed of 37 recently (2014-2018) issued Danish discharge permits. The permits were chosen through convenience sampling, where emphasis was put in part on achieving broad geographical representation and in part on giving examples of permits for the same type of discharge but issued by different municipalities.

Figure 3 shows a geographic overview of the sampled discharge permits, which cover the whole country. The Køge Bay area is densely represented, because we included a series of discharge permits for small rivers issued in connection with a newly established railway there. Many of the reviewed permits (18 out of the 37) were given to utility companies and addressed roof and surface runoff. This is considered the most abundant type of discharge permit generally issued in Denmark, and it is also the type of permit that most of the reviewed guidelines target. The reviewed permits also included 12 permits issued to BaneDanmark (a governmental body under the Ministry of Transport, Building and Housing, which is responsible for all Danish railways) and four permits issued to the Danish Road Directorate (who are responsible for all larger, national road connections such as highways and bridges). The remaining three permits included in the study were issued to private companies.

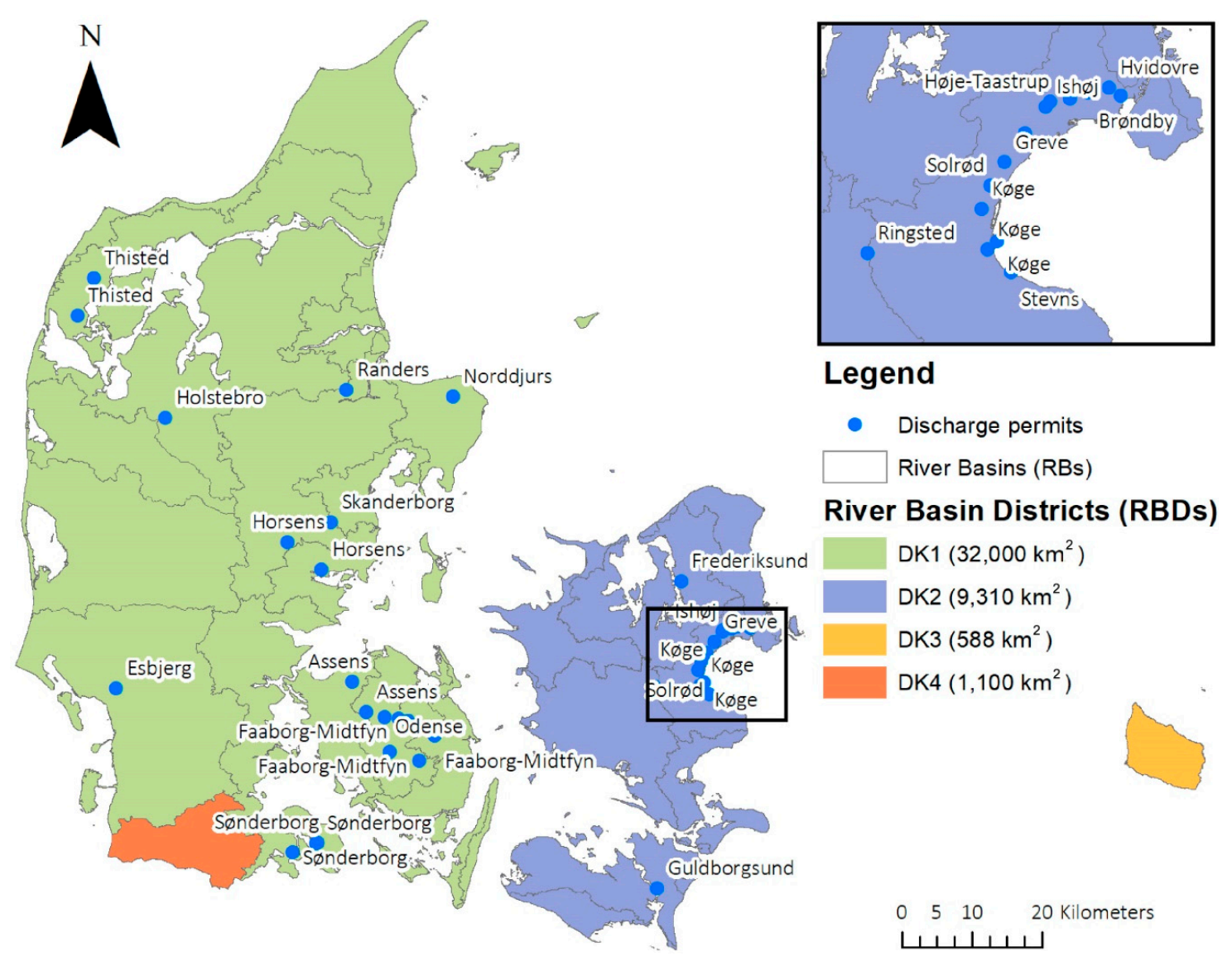

Figure 3. Geographical distribution of reviewed Danish discharge permits mapped against the Danish River Basins (RBs) (lines) and River Basin Districts (RBDs) (colors). Part of the DK4 district is in Germany, and not depicted on the map.

For reviewing the permits, a summary matrix was set up to help register parameters of interest as categorical and numerical variables. An overview of the summary matrix is presented in Table 1 with the main data categories and their subcategories. The chosen categories were inspired by a report written by the Danish Water Pollution Committee [89] and the work of Johansen and Hvitved-Jacobsen (1992) [90]. 
Table 1. Overview of parameters registered in the summary matrix for the permit review.

\begin{tabular}{cccccc}
\hline Administration & Recipient & Catchment & BAT ${ }^{1}$ & Quantity & Quality \\
\hline $\begin{array}{c}\text { Authority, } \\
\text { applicant and } \\
\text { date }\end{array}$ & $\begin{array}{c}\text { Name, type, } \\
\text { environmental } \\
\text { objectives } \\
\text { and } \\
\text { current status }\end{array}$ & $\begin{array}{c}\text { Area, land use } \\
\text { type, upstream } \\
\text { overflows, etc. }\end{array}$ & $\begin{array}{c}\text { Chosen technique, } \\
\text { performance } \\
\text { requirements, } \\
\text { sizing, } \\
\text { maintenance, } \\
\text { contingency } \\
\text { plans, etc. }\end{array}$ & $\begin{array}{c}\text { Conditions and } \\
\text { requirements } \\
\text { regarding } \\
\text { maximum } \\
\text { discharge (flow) } \\
\text { and yearly } \\
\text { discharge (volume) }\end{array}$ & $\begin{array}{c}\text { Overall conditions } \\
\text { for water quality, } \\
\text { specific } \\
\text { requirements for } \\
\text { ELV }^{2} \text { or treatment } \\
\text { performance level } \\
\text { of BAT }^{1}\end{array}$ \\
\hline
\end{tabular}

${ }^{1}$ Best Available Technique, see Sections 3.1 and 3.2.3, ${ }^{2}$ Emission Limit Value, see Section 3.1.

Results from the review of discharge permits will be presented in Section 4, while we first present results from the review of the regulatory practice in Section 3. As an aid to the reader, Table A1 in the Appendix A provides an overview of all abbreviations, while Table A2 lists translations of technical terms and phrases from the Danish references used in the reviews.

\section{Results of Review of Regulatory Practice}

\subsection{The EU Water Framework Directive and the Floods Directive}

The main European directives relevant to the management of urban stormwater runoff are:

- $\quad$ The EU Water Framework Directive (WFD) from 2000 [26]

- $\quad$ The EU Floods Directive (FD) from 2007 [27]

- The Environmental Quality Standards Directive (EQSD) from 2008 [91], which is a daughter directive of the WFD.

The WFD is an "umbrella directive" aiming to reduce the fragmentation that existed in many of the earlier pieces of European water legislation adopted since the 1970s [92] by providing a framework for integrated river basin management. The overall goal of the WFD is to protect all surface and groundwaters and achieve "good status" for all waters by 2015 with the possibility of delaying until 2027. To ensure that the desired status will be met, an assessment should be made of the current conditions in the waterbodies and this knowledge should be used for creating a Programme of Measures (PoM).

"Good status" consists of two components: "good chemical status" is determined by whether or not the recipient complies with Environmental Quality Standards (EQSs) established for chemical substances, notably those priority substances and priority hazardous substances that are defined in the EQSD [91] and "good ecological status" is defined in terms of the quality of the biological community with hydromorphological, physico-chemical and chemical supporting elements that are determined by the member states (see full list of Quality Elements (QEs) in Table 2). The "one-out-all-out" principle applies, meaning that good status is only achieved when compliance is carried out for all the listed chemical substances or for all of the quality elements. To support the work towards the status goals, the WFD includes an elaborate description of how to set up local EQS standards for water, sediment or biota (preferably by looking at both acute and chronic effects) and how to design monitoring programs for surveillance, operation and investigation.

The directive promotes catchment-based water management by looking at geographical and hydrologic River Basin Districts (RBDs) rather than at administrative or political boundaries defined for other purposes. These RBDs may span several countries for large rivers, and the implementation of the WFD requires RBMPs to be established and updated for each RBD in cycles of six years. This was done for the first time for 2009-2015, the second time for 2015-2021 and will be done a third and final time for the cycle 2021-2027. The RBMPs play an important role, in that they should report progress and coordinate efforts through the PoM in a manner that ensures cost efficiency and citizen involvement. 
Table 2. Quality elements (QEs) for the ecological status of surface waters (lakes/rivers) and indices used for their assessment in Denmark.

\begin{tabular}{|c|c|c|c|}
\hline QE & EU WFD & DK (River) & DK (Lake) \\
\hline \multirow[t]{4}{*}{ Biological elements } & Composition and abundance of aquatic flora $(\mathrm{r} / \mathrm{l})$ & $\begin{array}{l}\text { Danish aquatic plant } \\
\text { index for rivers }\end{array}$ & $\begin{array}{c}\text { Danish aquatic } \\
\text { plant index for lakes }\end{array}$ \\
\hline & $\begin{array}{l}\text { Composition and abundance of benthic } \\
\text { invertebrate fauna }(\mathrm{r} / \mathrm{l})\end{array}$ & $\begin{array}{l}\text { Danish aquatic fauna } \\
\text { index for rivers }\end{array}$ & \\
\hline & $\begin{array}{l}\text { Composition, abundance and age structure of } \\
\text { fish fauna }(\mathrm{r} / \mathrm{l})\end{array}$ & $\begin{array}{l}\text { Danish fish index } \\
\text { for rivers }\end{array}$ & $\begin{array}{l}\text { Danish fish index } \\
\text { for lakes }\end{array}$ \\
\hline & $\begin{array}{l}\text { Composition, abundance and biomass of } \\
\text { phytoplankton (l) }\end{array}$ & & $\begin{array}{l}\text { Danish plankton } \\
\text { index for lakes and } \\
\text { algae biomass } \\
\text { measured as } \\
\text { chlorophyll a1 }\end{array}$ \\
\hline $\begin{array}{l}\text { Hydromorphological } \\
\text { elements supporting } \\
\text { the biological } \\
\text { elements }\end{array}$ & $\begin{array}{l}\text { Quantity and dynamics of water flow }(\mathrm{r} / \mathrm{l}) \\
\text { Connection to groundwater bodies }(\mathrm{r} / \mathrm{l}) \\
\text { River continuity }(\mathrm{r}) \\
\text { Depth and width variation }(\mathrm{r} / \mathrm{l}) \\
\text { Structure and substrate of river bed (r) } \\
\text { Quantity, structure and substrate of the lake } \\
\text { bed (l) } \\
\text { Structure of the riparian zone/shore (r/l) } \\
\text { Residence time (l) }\end{array}$ & \multirow{2}{*}{\multicolumn{2}{|c|}{$\begin{array}{l}\text { Each parameter is assessed } \\
\text { individually and compared } \\
\text { to "untouched" conditions }\end{array}$}} \\
\hline \multirow[t]{3}{*}{$\begin{array}{l}\text { Physico-chemical and } \\
\text { chemical elements } \\
\text { supporting the } \\
\text { biological elements }\end{array}$} & $\begin{array}{c}\text { Thermal conditions }(\mathrm{r} / \mathrm{l}) \\
\text { Oxygenation conditions }(\mathrm{r} / \mathrm{l}) \\
\text { Salinity }(\mathrm{r} / \mathrm{l}) \\
\text { Acidification status }(\mathrm{r} / \mathrm{l}) \\
\text { Nutrient conditions }(\mathrm{r} / \mathrm{l}) \\
\text { Transparency }(\mathrm{l})\end{array}$ & & \\
\hline & $\begin{array}{l}\text { Pollution by all priority substances identified as } \\
\text { being discharged into the body of water }(\mathrm{r} / \mathrm{l})\end{array}$ & \multicolumn{2}{|c|}{ EQS from EQSD [91] } \\
\hline & $\begin{array}{l}\text { Pollution by other substances identified as being } \\
\text { discharged in significant quantities into the body } \\
\text { of water }(\mathrm{r} / \mathrm{l})\end{array}$ & \multicolumn{2}{|c|}{ EQS from Statutory Order no. 1625 [45] } \\
\hline
\end{tabular}

A core element of the WFD is "the combined approach for point and diffuse sources" of pollution that are discharged into surface waters [92]. The approach has been implemented differently across member states [93], but the overall implication from the directive is that measures are to be taken on both the source and the effect side. On the source side, this includes Best Available Techniques (BATs) for point sources, Best Environmental Practices (BEPs) for diffuse sources or the use of Emission Limit Values (ELVs). On the effect side, EQSs for the surface waters must also be respected, and if these cannot be met, then further measures must be taken [92]. For discharges of urban stormwater, the combined approach creates an opportunity for using the source-oriented ELVs to target acute lethal damages to aquatic organisms, while the effect-oriented EQS objectives can target long-term chronic stress in the whole recipient [93]. Typical relations of ELVs to EQSs range between a factor of five and 1000 [94].

The FD was adopted as a response to the rising frequency of damaging floods [95] in Europe and aims to manage the flood risks (the combination of flood probability and consequences) to human health, the environment, cultural heritage and economic activity. Each European member state must use a designated spatial unit to manage the FD implementation; most apply the same unit as in the WFD implementation and this is also the case in Denmark (the RBDs). The implementation of the FD required the national government to carry out preliminary flood risk assessments by 2011 for both inland and coastal waters in order to identify Areas of Potential Significant Flood Risk (APSFRs), and to draw up flood hazard and risk maps by 2013. Member states were furthermore required to draw up Flood Risk Management Plans (FRMPs) focused on prevention, protection and preparedness for the identified APSFRs by 2015 [96]. These plans should take into account the likely impacts of climate changes on flood occurrence and be renewed every 6 years as ongoing planning cycles. The FD is explicitly required to be integrated with the WFD in order to promote integrated river basin management $[38,96]$, and the planning cycles have thus been synchronized, so that the first cycle of FRMPs can be coordinated with second cycle of RBMPs. 
Waylen et al. [71] used a survey and interviews with key actors leading the creation of the management plans associated with WFD and FD implementation across member states. The article points out that the two directives have both competing and overlapping agendas, which for the WFD are expressed as clear targets for the status of the water body to be met before 2027, while for the FD, these are broader objectives without a final deadline. One interviewee even described the directives as having contrasting focuses, which were respectively eco-centric (WFD) and human-centric (FD). The study found that collaboration initiatives often focused on bridging between actors working on water quantity and quality issues, but that there was also a demand for cross-level collaboration. Here, the regional regulators called for more support from the national policymakers in order to advance the integration of the directives, while at the same time, bottom-up approaches (such as local pilot projects) were highlighted as essential in building a vision for integration.

\subsection{Danish Implementation of the Water Framework Directive and the Floods Directive}

\subsubsection{The Water Framework Directive and River Basin Management Plans in a Danish Context}

The Danish water environment has undergone significant improvements over the last 30 years, which can, e.g., be ascribed to the upgrade from smaller, decentralized WWTPs to bigger, centralized and more efficient plants, as well as the efforts to mitigate agricultural emissions [64]. As such, the WFD is just one chapter of a much longer story of environmental water management, and its implementation has therefore been a gradual mergence with existing practices [77].

The protection of surface and groundwater is mainly regulated by two laws: the Environmental Objectives Act [41] and the Water Planning Act [44]. Together, these laws constitute the legal foundation for the Danish RBMPs, which contain an overview of the current status in the water environment, environmental objectives and a PoM, and as such serve as an information tool on the WFD implementation progress.

For the current status and the objectives, the water bodies are evaluated using the environmental classes: (1) high, (2) good, (3) moderate, (4) lower or (5) bad, based on both the ecological status and the chemical status in accordance with WFD principles. To determine the ecological status, aquatic flora and fauna indices are used as biological QEs, while a comparison to reference conditions is used for the hydromorphological and physico-chemical QEs (see Table 2). Danish Statutory Order no. 1625 of 2017 defines recipient EQSs [45] by repeating the European substances, which are used for determining chemical status, and adding a list of national substances with general (chronic) and maximum (acute) concentration levels, which are used for the assessment of ecological status. For selected substances, Order no. 1625 also lists translations of the general concentration levels in the water column into biota and sediment concentration levels, which can be more operational to work with in the status monitoring.

Since there are no large rivers in Denmark, the country has been divided into 23 RBs that combine into four overall RBDs representing the mainland of peninsula Jutland and the island Funen (DK1), the islands Zealand (DK2) and Bornholm (DK3), and the southern part of Jutland (DK4, shared RBD with Germany) (see Figure 3). In the first planning cycle (2009-2015), RBMPs were published for each of the 23 RBs, while the second (2015-2021) and third (2021-2027) compile the plans at RBD level.

An overview of the planned deadlines in the Danish cycles for both the WFD and the FD is presented in Figure 4, with numbers indicating actions that are repeated in each cycle. It should be noted that in the first WFD cycle, the RBMPs were overruled by the Court of Appeal, which caused several delays. This means that the actual publication dates deviate a lot from the planned deadlines in the Figure, e.g., the first round of municipal action plans were delayed by five years. Note that also, for the RBMPs, the planning cycle is the time after the publication (left side, point 4), when the municipalities have to translate the PoMs into concrete projects, while for the FRMPs, the planning cycle is the time leading up to the publication (right side, point 3 ). 


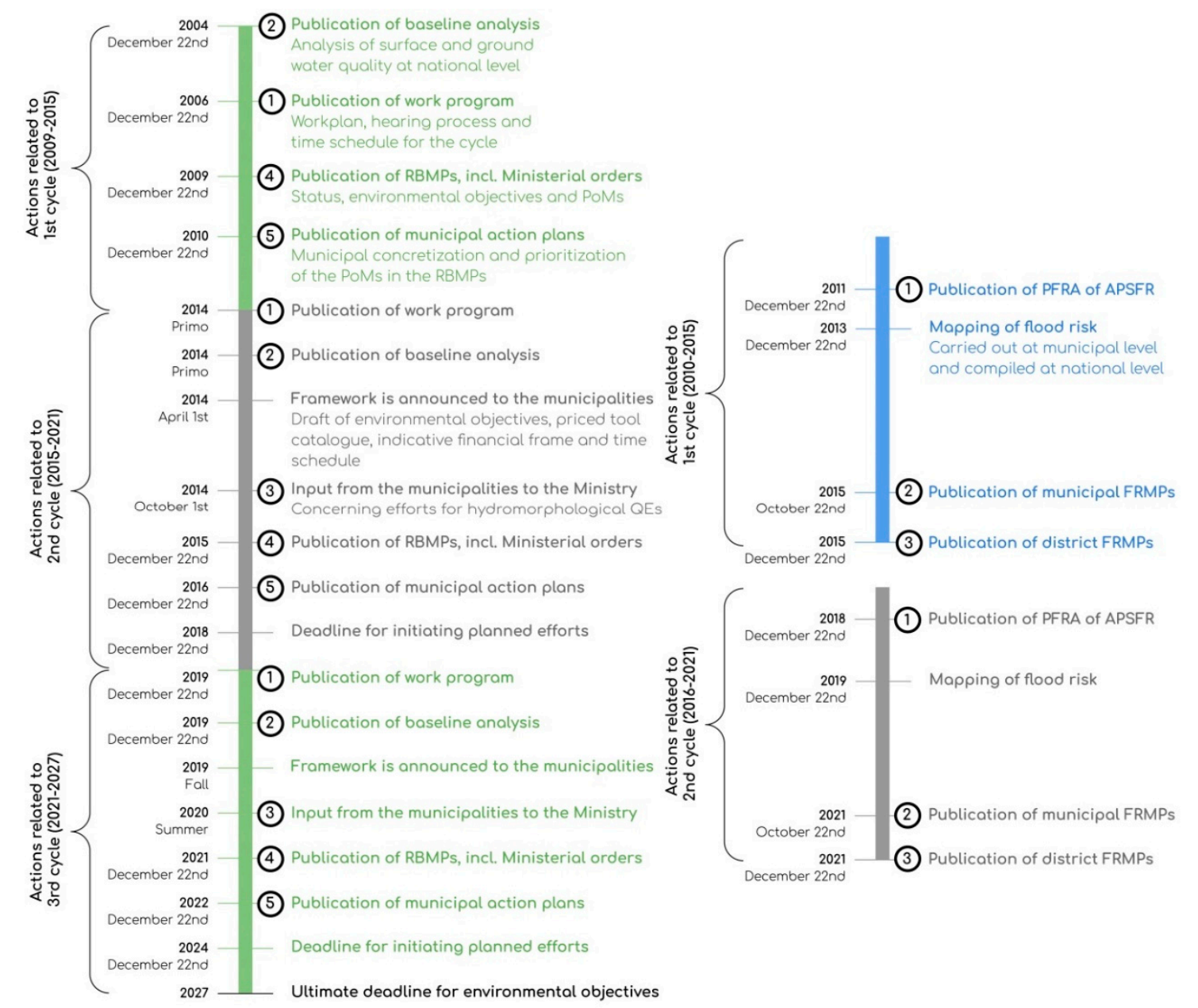

Figure 4. Timeline of the cycles for creating River Basin Management Plans (RBMPs) (left) and Flood Risk Management Plans (FRMPs) (right). The circled numbers are specific steps that are repeated in each planning cycle and they refer to actions in Figure 5.

Figure 5 maps out the Danish implementation of the WFD and the FD and illustrates the different levels at which activities connected to the RBMPs and FRMPs take place (with numbers indicating activities directly linked to the planning cycles in Figure 4). Denmark has chosen a rather centralized planning approach compared to other member states [76]. In the initial process leading up to the first planning cycle, the Danish government included regional and local authorities, agriculture, NGOs and other stakeholders through an open participatory approach. After realizing the high costs associated with WFD implementation, however, their involvement was limited, and instead a committee was appointed by the Ministry of Finance to calculate the most cost-efficient measures for WFD implementation [32,75]. Each planning cycle still holds some opportunity for the municipalities to influence the measures, but this is mainly reserved for ideas regarding the physical conditions of the recipients. Preceding each round of RBMPs, a work program is published by the Ministry with a timeline for the whole process and a description of new initiatives that will be launched to support the process (point 1 in Figures 4 and 5). The next step is a baseline analysis carried out by the Environmental Protection Agency (EPA), which describes current conditions in the water environment and whether actions are necessary in order to comply with the WFD. It is following this step that the municipalities are given the opportunity to use their local knowledge to make suggestions for the PoMs. To aid in this process, each RB will appoint a committee. This is administered by the municipality tasked with the secretarial duty for each RB, and the suggestions made by the RB committees (which are carried on as the municipal input to the RBMPs) will normally make it word by word into the RBMPs [65]. 


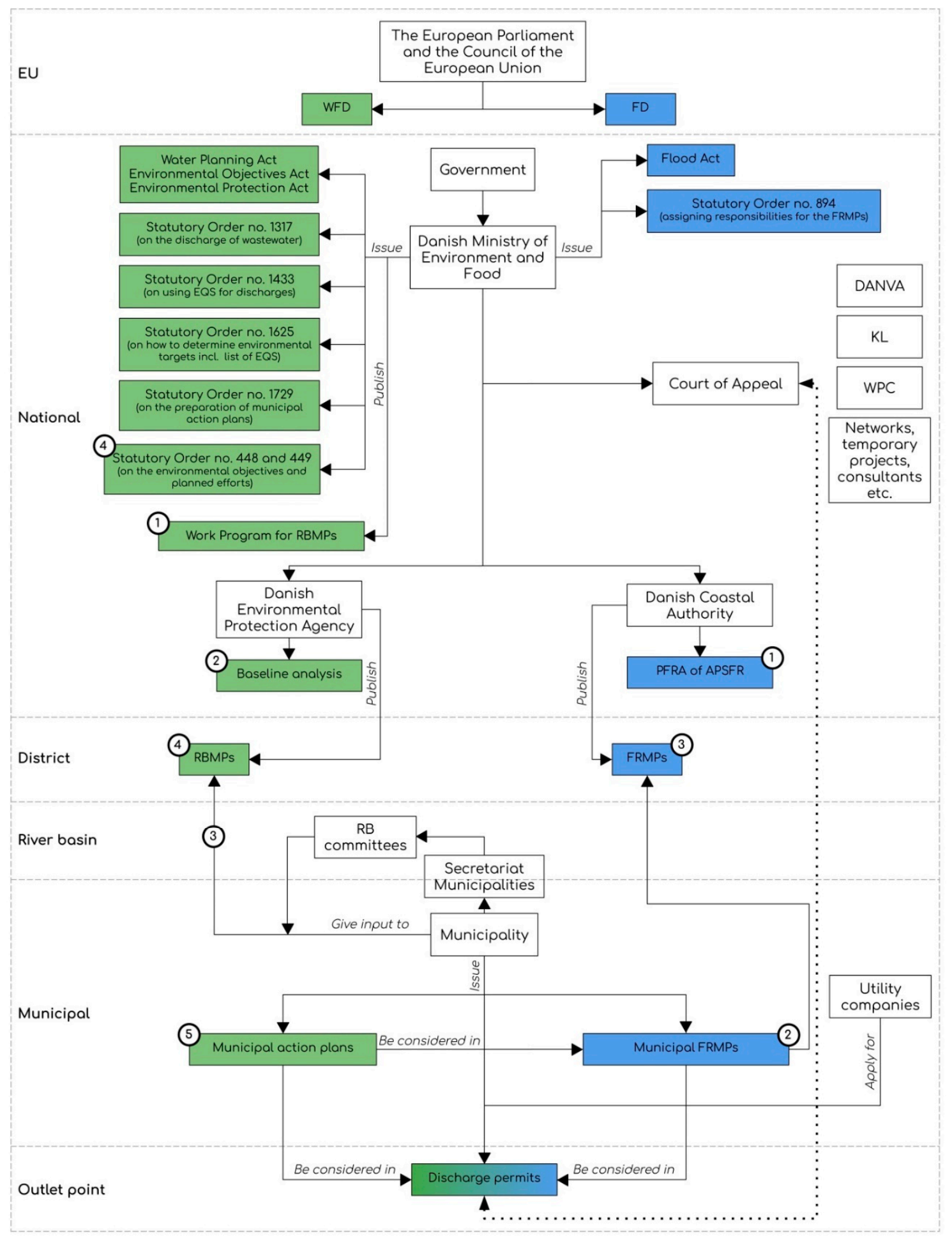

Figure 5. Illustration of the implementation of the Water Framework Directive (WFD) and the Floods Directive (FD) in a Danish context. Actors are marked by white boxes, while actions (or products) are marked by color. The circled numbers refer to specific steps that are repeated in each planning cycle (see Figure 4). The dotted, double-headed arrow shows the process of permits being appealed and verdicts influencing the continued permit practice.

The completed RBMPs are not in themselves legally binding, but they are accompanied by statutory orders [42,51], which manifest the set environmental objectives and describe the PoMs to be carried out. These statutory orders must be taken into account in all municipal planning, 
and furthermore, Statutory Order no. 1729 [43] compels the municipalities to create action plans that list and prioritize efforts to follow up on the PoMs from the RBMPs. However, as the PoMs are rather specific, how much these municipal action plans can be adapted to fit local conditions is limited [76]. Overall, this means that objectives and measures are decided at the national level and published at the RBD level, while the actual implementation takes place at the municipal level. The main administrative levels for stormwater discharge regulation thus become the national level (policy formulation) and the municipal level (policy implementation), with the RB and RBD levels playing no significant role.

In the PoMs, measures for existing stormwater discharges only target discharges from combined systems, meaning that there is no legal description of measures to be taken for discharges from separate systems-only the overall requirement that the environmental objectives for the recipient should be met. For new discharges of stormwater, it is required that the environmental objectives for the recipient are taken into consideration, as well as other interests described in the municipal FRMPs, climate change adaptation plans, cloudburst management plans, contingency plans or other municipal plans (illustrated in the bottom cell of Figure 5).

A central element in defining recipient objectives is the designation of water bodies into categories of "natural", "artificial" or "heavily modified". Denmark has a remarkably high fraction of water bodies designated as "natural" compared to other member states [36,75]. For rivers impacted by stormwater outlets, a national guideline [62] specifically states that they should not be designated as "heavily modified", but rather the hydraulic load should be mitigated by delaying stormwater discharges. This strategy means that only very few of the lakes and rivers that receive water from urban discharges are exempted from living up to the "good status" objective. The current water body status in Denmark can be found in the RBMPs covering 2015-2021 [52] and is illustrated in Figure 6. The majority of the recipients are currently not being monitored, and among the monitored recipients, roughly $75 \%$ of the rivers and all of the lakes meet the target for ecological status, while only $19 \%$ of the rivers and $8 \%$ of the lakes meet the target for chemical status.

The baseline analysis for the third cycle is based on data collected from 2014-2018, and it includes a calculated risk of not complying with the environmental objectives before the 2027 deadline. For ecological status, $93 \%$ of rivers are included in the baseline analysis, and it is estimated that only $49 \%$ of these will be able to meet the objectives by the deadline, while $51 \%$ will not. For chemical status, only $4 \%$ of rivers are included, and here it is estimated that only $23 \%$ of these will be able to meet the target by the deadline [66].

In the beginning of 2019, the European Commission published an assessment report on the Danish implementation of the WFD [36]. The report encourages improving the monitoring of surface water to cover all QEs for ecological status assessment (examples of gaps are phytobenthos in rivers, benthic invertebrates in lakes and a series of physico-chemical QEs in rivers) and to expand the monitoring of chemical status (currently only carried out at $1.51 \%$ of total monitored sites). Furthermore, it comments on the missing establishment of reference conditions for the hydromorphological and physico-chemical QEs, suggests completing the development of assessment methods for the classification of ecological status and asks for data quality to be reported.

For the next round of RBMPs (2021-2027), the newly published work program [65] has announced a series of initiatives. For the assessment of ecological status, new indices will be introduced for biological QEs, such as phytobenthos and a new assessment of how different levels of hydromorphological and physico-chemical QEs effect or support the biological QEs (see Table 1). The work program also indicates an ambition to initiate projects for improving the knowledge foundation of climate change impacts on lakes, coastal water and ground water (excluding rivers), and to launch a series of projects targeting discharges of wastewater (excluding separated systems). Regarding hazardous substances, efforts will be made to identify pressures from both diffuse and point sources and to determine additional EQSs based on existing knowledge. 

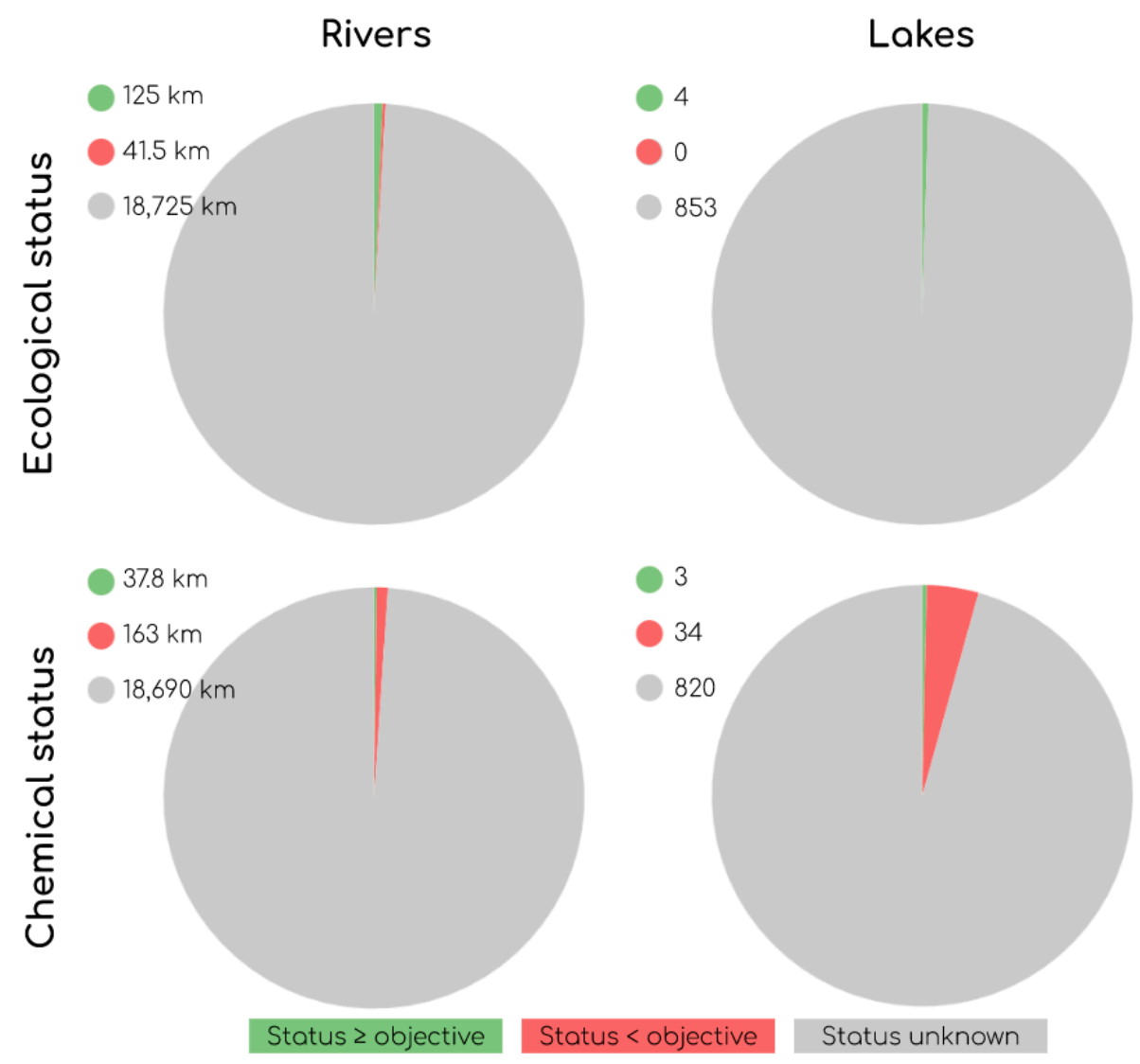

Figure 6. Status of Danish rivers and lakes. The lengths of rivers and the number of lakes within each status category can be seen at the top left of each circle diagram. Data from the second cycle of the River Basin Management Plans (RBMPs) [52].

\subsubsection{The Floods Directive and Flood Risk Management Plans in a Danish Context}

The FD is implemented through the Danish Flood Act [48] and Statutory Order no. 894 on how to assess and manage flood risks [49]. As illustrated in Figures 4 and 5, the FRMP process begins with the Coastal Authority under the Ministry of Environment and Food carrying out a Preliminary Flood Risk Assessment (PFRA) of areas where extreme floods can have major financial and human consequences. The assessment focuses on river flooding, coastal flooding and a combination of the two [48], while floods from stormwater systems are excluded, as is possible within the FD definition of flooding [96]. In the first cycle (2010-2015), the PFRA led to the identification of 10 APSFRs across 22 municipalities [68], and in the second cycle (2016-2021), this was reevaluated to 14 APSFRs across 27 municipalities [69]. It is then up to the municipalities to draw up a municipal FRMP that describes initiatives for prevention, protection and preparedness against flood risks. By the end of the cycle, the municipal FRMPs are sent to the Coastal Authority to be compiled into FRMPs at the RBD level and published by the Minister of Environment and Food.

Parallel to the mapping of river and coastal flood risk in the first cycle, all municipalities were asked to map flood risks related to capacity in the drainage systems before the end of 2013, and draw up climate change adaptation plans with prioritized mitigating measures to be taken [97]. Many municipalities have since then supplemented these with cloudburst management plans qua recommendations made by the Danish Water Pollution Committee in 2017 [81].

It is up to the municipality to ensure congruence between the municipal FRMPs and other municipal plans, such as climate change adaptation plans, cloudburst management plans and contingency plans. There is an obvious potential for the coordination of measures here, and the municipalities are even encouraged to use existing climate change adaptation plans or contingency plans as a basis for the 
municipal FRMPs [68]. The municipal FRMPs should also include a list of all other relevant statutory initiatives being carried out, including initiatives related to the RBMPs through the Danish WFD implementation [70].

It is not a legal requirement to create the municipal FRMPs in cooperation with other municipalities who share the same APSFR, but it is encouraged. This means that, even though the FRMPs are compiled at the RBD level, all the planning of measures may take place, not at the RBD, RB or APSFR levels, but at the municipal level (see Figure 5). Furthermore, this means that the coordination of RBMPs and FRMPs can only take place in a one-way flow at the municipal level, and the window of opportunity for doing so was 22nd of December 2014 to 22nd of April 2015 (for the first cycle) and will be 22nd of December 2020 to 22nd of April 2021 (for the second cycle) when taking into account the hearing periods for municipal and district level management plans [68].

A recent assessment report by the European Commission about the FD implementation in Denmark [37] has reviewed the FRMPs from the first cycle (see Figure 4) and called for further and more consistent information on how the initial flood analysis and mapping is used to make FRMPs; more information on how the FRMPs are coordinated with the National Climate Change Adaptation Strategy; further information on the prioritization of measures, including the criteria used; and information on how the implementation of measures will be monitored. The report also suggests that a more uniform approach is considered in the plans, in terms of the level of detail and choice of strategy, as they are currently quite diverse because they are a mergence of municipal FRMPs. To better this, greater information exchange among the various administrations is advised.

\subsubsection{Discharge Permits for Separate Stormwater Systems in Denmark}

From the statutory orders that accompany the RBMPs, it is given that, if (a) the environmental target is not currently being met in the recipient, then discharges must not prevent that from being achieved, and if (b) it has been met, then discharges must not reduce the status-even if it is above the target [42]. To ensure this, the discharge permit system has been designed to take the environmental objectives, expressed as EQSs, and translate them into ELVs, BATs and BEP requirements [77]. However, for separate stormwater discharges, this system appears less clear.

The Danish practice of using permits to regulate urban stormwater discharges is rooted in the Environmental Protection Act [40], which prohibits any discharge to surface waters that may cause pollution in the recipient, but also presents the option of granting a permit for wastewater discharges. In this context, the term "wastewater" also covers stormwater from residential, industrial or in other ways built-up areas. While the Environmental Protection Act does not specify under which conditions wastewater discharges can be permitted, the Wastewater Statutory Order [46], issued by the Danish EPA, elaborates that requirements can be made in the permits with reference to EQSs in the recipients. EQSs can be found in Statutory Order no. 1625 [45], and their application for discharges is described in Statutory Order no. 1433 [47] (and was previously described in Statutory Order 1022 of 2010 [50]). However, Statutory Order no. 1433 exempts "normally polluted separate stormwater discharges", because, even though these discharges take place at an outlet point, the pollution that they carry comes from diffuse sources [77]. This leaves behind a gap for how to determine permit conditions for separate stormwater discharges. In response to this, the Danish Nature Agency stated in 2011 that separate stormwater discharges should still be regulated, and that this could be done through the use of SCM performance requirements with reference to BATs and BEPs for mitigating both the hydraulic load and discharges of suspended solids and organic matter [85]. While this statement on one hand provides a regulatory approach, it also reduces the water quality aspect to a focus on particulate substances, and ignores pollutants relevant to the chemical status.

BAT is a dynamic standard, and in Denmark there is no formal procedure for when a technique is elevated to be considered a BAT. Instead, this is determined with reference to publications and statements from the Danish EPA, industry standards or verdicts from the Court of Appeal under the Ministry of Environment and Food. A discharge permit can be appealed within four weeks of issuance; 
however, separate stormwater discharges can only be appealed if they include runoff from roads, train rails or impervious areas used for parking more than 20 cars.

The discharge permits are normally issued by the municipal local council, pending formal application [54]. Applicants for permits are predominantly utility companies tasked with water services, but they can also be public institutions, private companies or citizens with a direct drainage need that circumvents the utility systems. After a permit is granted, the same issuing authority will ensure that the permit conditions are being complied with, except for permits covering stormwater discharges (as well as discharges from wastewater treatment plants and emergency overflows from pumping stations). Here, the supervision duty falls back to the Danish EPA [98].

\subsection{Danish Guidelines for Separate Stormwater Management}

The following sections provide an overview of many of the relevant guidelines in this field by dividing the publishers into actor categories: (1) national governmental, (2) national non-governmental, (3) municipal and (4) industry.

(1) National governmental: Each of the WFD cycles are accompanied by a series of guidelines and tool catalogues published by or commissioned by the national authorities. An overview is provided in Table 3 below, but it should be noted that this is not an exhaustive list.

Table 3. Overview of guidance documents issued or commissioned by national authorities to accompany the Water Framework Directive (WFD) and the Floods Directive (FD) planning cycles. Titles have been translated from Danish.

\begin{tabular}{|c|c|}
\hline Cycle & Guidance Documents \\
\hline $\begin{array}{l}\text { WFD1 } \\
(2009-2015)\end{array}$ & $\begin{array}{l}\text { Danish EPA (2006): Unit costs and pollution control for different environmental measures [55] } \\
\text { By- og Landskabsstyrelsen (2010): Guidelines for making PoMs [56] } \\
\text { By- og Landskabsstyrelsen (2010): Tool catalog for planning RBMP measures [58] } \\
\text { Danish Nature Agency (Undated): Tool catalog for planning RBMP measures [99] } \\
\text { Danish Nature Agency (2012): Guidelines for planning measures [57] }\end{array}$ \\
\hline $\begin{array}{l}\text { WFD2 } \\
(2015-2021)\end{array}$ & $\begin{array}{l}\text { Aahus University (2014): Measures for realizing RBMPs and targeted areal regulation [100] } \\
\text { COWI on behalf of Danish Nature Agency (2014): Measures for point sources [101] } \\
\text { Danish EPA (2016): Guidelines for making RBMPs [62] } \\
\text { Danish EPA (2017): Guideline for Statutory Order on PoMs for RBDs [59] }\end{array}$ \\
\hline $\begin{array}{l}\text { WFD3 } \\
(2021-2027)\end{array}$ & $\begin{array}{l}\text { Aarhus University (2019): Measures to improve physical conditions in rivers [102] } \\
\text { COWI on behalf of Danish EPA (2019): Measures for point sources [103] }\end{array}$ \\
\hline $\begin{array}{l}\text { FD1 } \\
(2010-2015)\end{array}$ & Danish Nature Agency (2014): Guideline for FRMPs [68] \\
\hline $\begin{array}{l}\text { FD2 } \\
(2016-2021)\end{array}$ & $\begin{array}{l}\text { Danish Coastal Authority (2018): Reevaluation of APSFRs [69] } \\
\text { Danish Coastal Authority (2020): How to make an FRMP [70] }\end{array}$ \\
\hline
\end{tabular}

For all three WFD planning cycles, the guidelines focus exclusively on $\mathrm{BOD}_{5}, \mathrm{~N}$ and $\mathrm{P}$, while chemical pollutants are not directly addressed (unless we look at groundwater as a recipient). The separation of stormwater is mentioned as a measure against Combined Sewer Overflows (CSO)s, but separate stormwater discharges as a pressure take up very little space in the guidelines and are mainly presented as a source of hydraulic load (not pollutant load). The only measure mentioned in the tool catalogs for these discharges is detention ponds, though the catalog on unit costs also includes a section on infiltration measures. The guidelines that specifically support the municipalities in giving their input to the RBMPs (step 3 on the left in Figures 4 and 5) focus solely on physical conditions in the recipient with no attention to chemical or physico-chemical QEs.

In addition to the references mentioned in Table 3, there are national guidelines designed for assisting other processes than those directly related to the WFD and FD, but which are still relevant to the regulation of stormwater management. Central examples of this are the Wastewater Guideline [54] or guidelines related to the production of climate change adaptation plans $[60,61,104,105]$. 
(2) National, non-governmental: From a national hold, there are three main actors who publish guidelines apart from the governmental authorities (also indicated at the national level in Figure 5): the Water Pollution Committee (WPC), the Danish Water and Wastewater Association (DANVA) and Local Government Denmark (KL). WPC is a specialist group hosted by the Danish Society of Engineers, IDA, which is recognized as a national standards body by the European Committee for Standardization (CEN) [106]. They publish technical papers on, e.g., design principles for urban drainage infrastructure, rainfall statistics and methods for calculating economically optimal protection levels for cloudburst [79-81]. DANVA is a national interest organization for utility companies, and their guidelines primarily focus on the practical issues regarding project engineering and maintenance for their members [107]. KL is an interest organization for all Danish municipalities, and within this field, their focus has been on producing guidance documents for the local municipal authorities. DANVA and KL have co-authored a series of publications, e.g., a guideline for issuing discharge permits [78], and in general, many of the national guidelines are created in cooperation with universities, consultants, utility companies or municipalities. Apart from WPC, DANVA and KL, several thematic networks also exist at the national level [108]. They normally work by knowledge sharing through workshops and conferences, but will occasionally publish guidelines or even guides to guidelines [109-111]. Furthermore, many of the universities produce guidelines either in combination with the national authorities, national networks or even as industry collaborations [100,102,112-114].

(3) Municipal: Many municipalities have chosen to produce their own guidelines for how to work with discharges of urban stormwater. These are, to some extent, a representation of local politics and interest, but they also send a very clear message that the national regulatory framework and guidelines do not constitute sufficient support for the local water authorities. The municipal guidelines are often created with help from consultants and can be addressed at both sides of the outlet point, e.g., in the form of a recipient analysis or as a guideline on permit conditions with recommendations for the choice of BAT, for peak flow control options, the choice of dimensioning approach, etc. [115].

(4) Industry: Many industries (e.g., land developers or large-scale production companies) have their own guidelines for managing stormwater, as they are experts on the specific runoff coefficients and pollutant profiles relevant to their type of land use. Sometimes the actors in this group will also be applicants for discharge permits. There are two examples of this in the permit review: BaneDanmark and the Danish Road Directorate. Both are, in fact, governmental agencies, but as their incentive for producing guidelines comes from their task of constructing and managing state-owned railways and roads, their motive may be compared to that of a private developer. BaneDanmark and the Danish Road Directorate have both produced thorough materials on the volumes and composition of stormwater runoff from their properties, as well as propositions for measures to be taken before discharge to recipients $[87,88,116-118]$.

Overall, there is a great abundance of guidelines within the field of stormwater management published by many different actors and targeting different processes or audiences. This testifies to the cross-organizational and inter-disciplinary nature of stormwater government, and illustrates the many considerations to be balanced when making regulatory decisions. Sometimes, recommendations made in these guidelines are referenced in verdicts from the Court of Appeal under the Danish Ministry of Environment and Food, and thereby inadvertently elevated to a status of national standard, but this is a rare and rather unstructured way of qualifying the many publications. In the meantime, it is up to the local regulators themselves (in collaboration with permit applicants) to navigate critically through the jungle of guidelines and recommendation gaps to find the right arguments for backing their decisions.

\section{Results of the Review of Discharge Permits}

The conditions put forth in the reviewed Danish discharge permits could generally be divided into three categories: (1) peak flow control requirements, which put a limit on the maximum discharge from the outlet point to the recipient and therefore require the detention of excess flow upstream from the discharge point; (2) BAT requirements, where a certain technology type and performance level 
is demanded for managing the discharge; (3) and ELV requirements that limit the outlet of specific substances to certain maximum concentrations or total loads.

\subsection{Peak Flow Control Requirements}

According to the Ministerial Wastewater Guideline [54], peak flow control should be exercised to accommodate the hydraulic capacity of the recipient and a maximum permitted outflow of $1-2 \mathrm{~L} / \mathrm{s} / \mathrm{ha}_{\text {total }}$ is suggested to mimic natural runoff conditions. Prior recommendations have been $1-3 \mathrm{~L} / \mathrm{s} / \mathrm{ha}_{\text {impermeable }}$ (for rivers without hydraulic problems) or 1-2 L/s/haimpermeable (for rivers that are hydraulically challenged) from the regional plan for the Greater Copenhagen Area [119] and $1 \mathrm{~L} / \mathrm{s} / \mathrm{ha}$ total from the first planning cycle of RBMPs [63].

The review revealed a great convergence towards using peak flow control conditions, as 32 of the 37 analyzed permits dictated a value of maximum outflow at the discharge point. Note that none of these permits used differentiated peak flow control (e.g., based on summer/winter season), but all specified one specific limiting flow value to comply with. Among the 32 permits with peak flow control conditions, 18 made no further requirements for water quality control than the peak flow constraint.

When looking at the specific values for maximum outlet flow in the permits (Figure 7), the impression is that either a local assessment is made or a value of approximately $1 \mathrm{~L} / \mathrm{s} / \mathrm{ha}_{\text {total }}$ is used, which echoes the mixed recommendations mentioned above. The lower values in Figure 7 generally come from assessments of the natural flow regime in the recipients (measurements or calculations of the 2-year median maximum flow divided by the upstream catchment area), and the higher values generally come from the assessment of hydraulic capacity in the recipients (analysis of erosion and flood risks). This latter method is promoted in newer guidelines [78], and allows for maximizing the permitted peak flows in a way that is tailored to the local conditions.

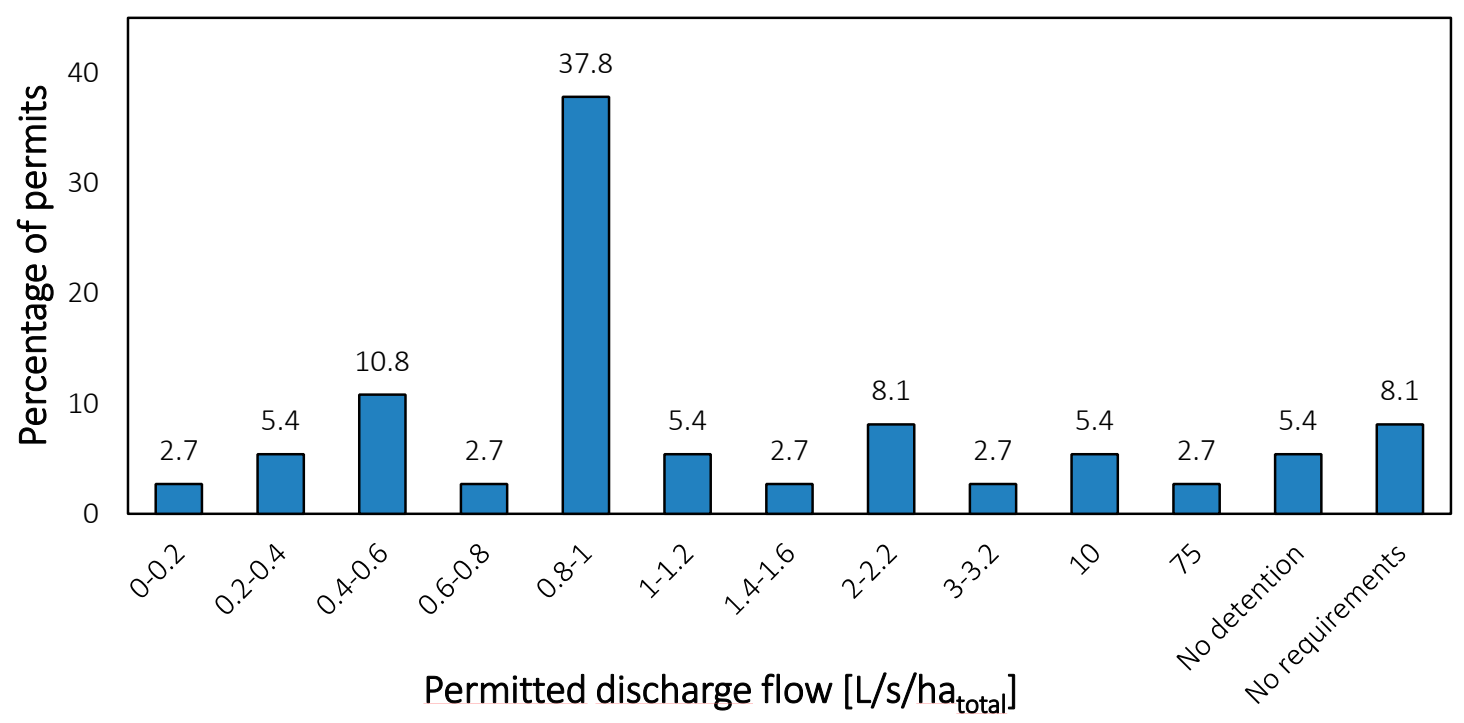

Figure 7. Distribution of the maximum permitted outlet flow in the reviewed permits.

Though Figure 7 uses the unit $\mathrm{L} / \mathrm{s} / \mathrm{ha}_{\text {total }}$, a handful of the permits conditioned the peak flow with reference to the impermeable area. Twelve of the permits did not provide sufficient information to determine the size of both the total and impermeable areas that runoff should be discharged from, and several of these had no information on area size at all.

It should also be noted that only two of the permits referenced adjacent discharges, and none of the permits presented complete overviews of other discharges made to the same recipient. This means that all assessments on permissible outflow were made from the perspective of only that single discharge point. 


\subsection{Requirements for Best Available Technique}

The BAT requirements put forth in the permits can be divided into three subcategories: (1) requirements regarding the choice of SCM technique; (2) requirements regarding the SCM dimensioning; and (3) SCM performance requirements with regard to ensuring water quality objectives.

\subsubsection{Technique}

The distribution of techniques referenced in the permits can be seen in Figure 8. The most popular technique is a Wet Detention Pond (WDP) followed by a Dry Detention Pond (DDP). A WDP works by detaining runoff and thereby reducing the hydraulic load on the recipient, while at the same time allowing for particles to settle in the wet volume that never dries out. In a DDP, all water will eventually drain from the pond, which means that it is less able to detain particles. The use of DDPs is recommended in industry guidelines published by BaneDanmark $[87,88]$ as the best measure for runoff from rail areas, because these are considered to have less particle-associated pollution, compared to, e.g., road surfaces. The BaneDanmark permits also mention that measures must be taken to ensure the minimum use of pesticides for weed control along the rails, which could be considered as a BEP requirement used to justify the BAT choice. As the permit review contains a considerable amount of BaneDanmark permits, this skews Figure 8 towards DDPs, and at the same time demonstrates the implementation degree of recommendations from industry guidelines in the permit practice.

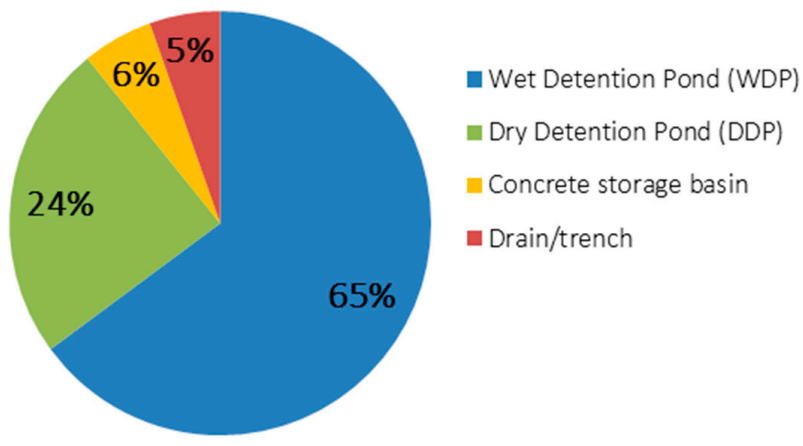

Figure 8. Distribution of referenced technique in the reviewed permits.

Though Figure 8 illustrates conformity about the overall choice of technique, there was a lot of variability in regard to supplementary design requirements, such as pond depth, volume of pre-treatment pond, inlet/outlet conditions, bottom membrane, brink facilities, sampling wells, maintenance, etc.

Two of the reviewed permits referred to first flush (the idea that the pollution load is heavier in the first part of the stormwater runoff event) in connection with the choice of technique. Neither of them presented a foundation as to why they believed there was a first flush effect in the runoff to be discharged, but in both cases, the phenomenon was referenced to defend a decision that was more economically feasible.

\subsubsection{Dimensioning Requirements}

Detention ponds (the predominant technique, see Figure 8) are dimensioned using the peak flow control value as a constraint, in combination with a return period for how often the pond can overflow [79]. In 30\% of the permits, these calculations are supplemented with a safety factor to account for uncertainties regarding the runoff calculations or to account for scenario uncertainties regarding projected climate changes in order to ensure that the installed measures can live up to the task for the duration of their service life [80]. Figure 9 (left) shows the distribution of return periods used for dimensioning, while Figure 9 (right) shows the distribution of the safety factor values. 

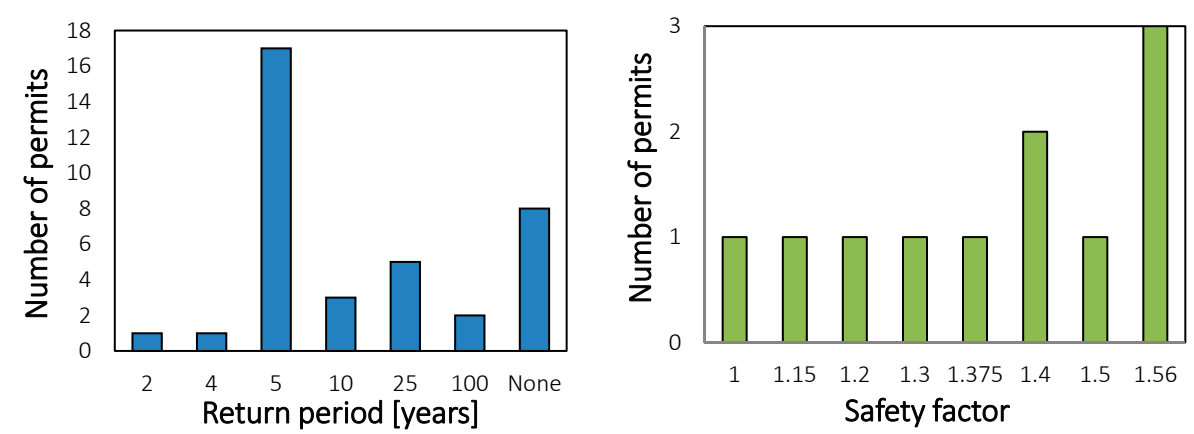

Figure 9. The return period for dimensioning (left) and the distribution of safety factor values (right) in the reviewed permits.

The required return period for dimensioning varies between 2 and 100 years, with a preponderance of 5 years. The regional plan for the Greater Copenhagen Area published in 2005 recommends using a 1- or 2-year return period [119], depending on whether the river is hydraulically challenged. For dimensioning drainage systems in cities, the WPC (and the European Committee for Standardization [106]) recommend using a minimum 5-year return period for separate systems and a 10-year return period for combined systems [79]. In 2011, the RBMPs covering the planning cycle 2010-2015 recommended using a 5-year return period [64], and in 2013 this was referenced in a verdict from the Court of Appeal as their perception of correct practice for discharge permits for surface water runoff [84].

Even though all the reviewed permits are more recent than this verdict, they do not all live up to a (minimum) 5-year return period, which in effect means that those that do not might be eligible for appeal, depending on the reasoning behind choosing a lower return period. Two of the permits mentioned that they had compromised when it came to return period, because the pond volume would otherwise become too big for the project to be economically feasible. The small peak at the 25-year return period seen in Figure 9, left, comes from the BaneDanmark permits, as BaneDanmark in their application material volunteer to dimension their DDPs to this level.

Normally, when dimensioning urban drainage systems, the applied return periods refer to how often a certain critical water level will be reached in the system or how often flooding is expected to occur [79]. But as the discharge permits apply to ponds in the border region between the urban systems and nature, exceeding the return period can have many different derived effects, including: leading to back water effects in the urban area and possibly sewer surcharge and flooding; if the capacity of a potential pre-treatment pond is surpassed, then it may be bypassed, which can increase the maintenance need of the main pond; and if the capacity of the main pond is surpassed, then this may cause increased discharge through the outlet, overflow to the recipient or overflow to the surrounding area. In the cases of increased discharge to the recipient, problems may arise in the receiving water body due to eroding flow velocities or water quality-related issues, such as unsettled particle-associated pollutants or oil films. Furthermore, the increased discharge may result in flooding downstream from the outlet point.

It was, however, very unclear from the reviewed permits what the consequence would be if the return period is surpassed. This indicates that the dimensioning approach has been uncritically adopted from the world of urban flood management without adapting it to this new setting, probably because this was the only guideline material available. A similar observation could be made from the safety factors used in the dimensioning calculations. Here, WPC has made recommendations regarding the use of safety factors for uncertainties and climate changes in urban flood management [80], and they explicitly mention in their guidelines that these should not be used for environmental impact assessments [82]. A verdict made by the Court of Appeal has determined that climate change factors may be used for BAT dimensioning at outlet points, but only to ensure that the outlet does not limit the performance level of the urban drainage system, not as a way of further protecting the 
recipient [120]. As seen in Figure 9 (right), most of the permits did not include safety factors at all, while those that did far from agree on which value to use. The latter is also true for the BaneDanmark permits, though they all concern the same runoff type (rail surfaces) and seem to be based on similar applications that reference the same guidelines $[87,88]$, so here we see a clear example of diversity in local permit conditions.

\subsubsection{Performance Requirements for Water Quality}

Many of the reviewed permits included no quantitative, operational requirements when it came to water quality, and instead relied on qualitative, hard-to-document restrictions, such as "the discharge must not prevent the recipient from meeting the environmental objectives", possibly supplemented with specifications for constructing a WDP. This tendency was also seen in a review of 14 permits performed by Klikovand (a municipal network for the water sector) in 2017 [121], and other examples of such qualitative requirements are, for instance "the discharge may not cause erosion in the recipient" or "the discharge may not cause algae formation in the recipient." However, a ruling made by the Court of Appeal in 2018 [86] stipulates that such general statements are not sufficient, and that operational conditions should be made to ensure that the general intent is carried out.

In most cases, the environmental objectives were referenced in the permit, but only for ecological status. Similarly, the current ecological status was often presented (and mainly as below target or unknown), while the chemical status was rarely mentioned (and, if so, then always as unknown). An evaluation of catchment runoff load was performed (if at all) using standard values for yearly average concentration, mainly for $\mathrm{N}, \mathrm{P}$ and COD. These were then compared to the estimated removal efficiency (relative percentage) of the chosen SCM technique, to justify that the discharge would not be the hindering factor in meeting the objectives for the recipient. This approach corresponds to those used for the yearly municipal reporting to the national point source database (PULS), which also focus on $\mathrm{BOD}_{5}, \mathrm{COD}, \mathrm{N}$ and $\mathrm{P}$ [122].

Ten of the reviewed discharge permits assumed specific standard removal efficiencies for the chosen techniques (all WDPs)—sometimes with reference to a specific guideline [123], but it was not always clear where the standard values came from. Table 4 shows the span of the removal efficiencies presented in the permits, revealing a great dispersion for most of the parameters. As one of the permits explicitly states (translated from Danish): "Other studies mention other removal efficiencies. It is unknown, what the exact retention of pollutants for the specific pond will be."

Table 4. Overview of ranges of removal efficiency for Wet Detention Ponds (WDPs) mentioned in ten of the reviewed permits. It should be noted that not all of these permits had values for all parameters.

\begin{tabular}{|c|c|c|}
\hline Parameter & Minimum & Maximum \\
\hline SS/TSS & $60 \%$ & $90 \%$ \\
\hline COD & $30 \%$ & $90 \%$ \\
\hline BOD & $20 \%$ & $75 \%$ \\
\hline Total-N & $10 \%^{1}$ & $60 \%$ \\
\hline Total-P & $10 \%{ }^{1}$ & $80 \%$ \\
\hline $\mathrm{Zn}$ & $40 \%$ & $85 \%$ \\
\hline $\mathrm{Pb}$ & $65 \%$ & $75 \%$ \\
\hline $\mathrm{Cu}$ & $60 \%$ & $80 \%$ \\
\hline Oil & \multicolumn{2}{|c|}{$80 \%$} \\
\hline PAH & \multicolumn{2}{|c|}{$90 \%$} \\
\hline
\end{tabular}

1 These values were specified as horizontal removal efficiencies. If excluded, then the minimum referenced value for total-N is $20 \%$ and for total-P, $40 \%$.

The ten permits that mentioned specific removal efficiencies included one out of a total of three permits from the same municipality, plus one out of a total of four permits from the Danish Road Directorate. This points to a difference in practice both within the same municipality and for the same type of runoff. 


\subsection{Requirements for Emission Limit Values}

Most of the reviewed permits addressed water quality conditions by referring to BAT and expected treatment performance expressed relative to the inlet concentration (see Table 4). One permit (made to a utility company) went one step further by estimating the expected yearly removal of $\mathrm{N}$ and $\mathrm{P}$ in absolute values, and one permit (made to the Danish Road Directorate) went as far as to mention that, given the chosen $\mathrm{BAT}$, they expected concentration levels below a specific value.

Actual substance-specific ELVs were used in only two discharge permits. Both were issued to BaneDanmark as temporary permits for runoff from construction sites for a new railroad, and as such, the stormwater in these two cases did not fall under the category "normally polluted separate stormwater discharges", which enabled the use of ELVs in the permits. Here, two interesting observations can be made:

- Although the permits were granted by neighboring municipalities in the Greater Copenhagen Area, to shared recipients and within less than a year of each other, the list of targeted pollutants (counting 14-25 specific substances such as heavy metals, chlorinated compounds, cyanide, etc.) were not completely the same.

- For similar, temporary permits given to BaneDanmark in other municipalities, no ELV requirements were made.

None of the ELVs in the two permits were presented with attention to short-term/long-term effects, allowed frequency of exceedance or other considerations to accommodate the natural variability in stormwater runoff concentration levels both during and in between events.

\section{Discussion}

5.1. The Exemption for Separate Stormwater Systems in the Implementation of the Water Framework Directive and Implications for Local Regulators

Denmark has maintained a focus on mitigating effects from direct discharges of wastewater, overflows from combined sewer systems, WWTP outlets and ind ustrial discharges [46], while discharges from separate stormwater systems have been largely overlooked. These discharges do, however, contain a wide range of pollutants $[8,15,124]$, and the Danish EPA itself estimates that the load of nutrients and organic material from separate discharges match the average load from CSOs on a yearly basis [34,55]. Proper regulation of separate stormwater discharges is therefore just as essential as the combined system overflows when it comes to ensuring good status in the receiving surface waters.

With this in mind, the current practice presents a dilemma. On one hand, the WFD has bound member states to achieve "good status" for all surface waters, which requires that all discharges be evaluated on the risks of hindering good status. On the other hand, the national implementation is based on the presumption that "normally polluted separate stormwater discharges" are unproblematic for complying with the environmental objectives [77]. This signals a knowledge gap of the potential effects that separate stormwater discharges may have on recipients, which causes them to be overlooked as a significant pressure. Consequently, no tools or plans are presented on how to work with these discharges at a strategic level (be that national, RBD, RB, APSFR or municipal). This puts the municipal authorities in a tight spot as to how they can ensure that the recipient objectives can be complied with, when the discharges are both exempted from permit conditions that reference EQSs and are omitted in PoMs in the RBMPs. Therefore, the dilemma transfers to the discharge permits, where it is reflected in the use of non-operational requirements or (occasionally) total disregard for stating conditions to ensure the environmental objectives for both ecological and chemical status can be met.

Separate stormwater discharges are still being regulated though, but the permit practice is largely focused on water quantity issues, with the dominating approach for regulation being flow control options. This resonates well with experiences made internationally [19]. For those permits that did set up additional requirements for water quality, the process seemed to be governed by a lot of uncertainty, 
both with regard to how to evaluate the expected pollution load from the catchment, how to evaluate the BAT performance and how to evaluate if compliance with environmental objectives in the recipients will be achieved.

Good stormwater management practice is a dynamic phenomenon, that both can and should be developed further [30], and the current lock-in situation, where separate stormwater discharges are both overlooked in the regulatory tool set (the statutory orders, national guidelines, RBMPs and PoMs) and simultaneously acknowledged as a pressure to be mitigated, definitely calls for some attention. At the single outlet scale, two different approaches may be employed to expand the knowledge foundation of the impacts that these discharges have on both the chemical and ecological recipient status: the explicit approach and the iterative empirical approach. For better explicit regulation, it is necessary to find tools that enable better estimation of catchment load, performance of the chosen BAT (or BEP) and resulting recipient effects and which can present these with relevant uncertainty levels. For the iterative empirical approach, it is crucial to improve and intensify recipient monitoring to assess the impact that stormwater emissions cause on the recipients. At the RB or RBD scale, there is an urgent need for a more holistic assessment of pressures and effects. It would be beneficial to create total emission inventories that also include the identification and mapping of pressures from all separate stormwater discharges. This information is present to some extent (volume, COD, BOD5, N and P) in the yearly municipal reporting to the national point source database (PULS) [122], but it needs to include chemical pollutants and be accountable, as well as accessible in a format to support effect evaluation and decision making for entire recipients at a time. With such an overview, it would both be possible to negotiate discharge conditions at a strategic level, rather than at the individual outlet point scale, and it would also make it possible to plan mitigating measures for separate stormwater discharges in the RBMPs. Examples of such measures could include re-visiting already existing discharge permits—as is also intended in the WFD [35] - but this is currently hard to carry out because it is difficult to point fingers at one particular discharge for hindering the desired recipient status without a complete overview of all the emissions and pressures. Carrying out these measures at the outlet and basin scale would significantly aid the municipal authorities and provide much needed backing for their regulatory decisions.

\subsection{The Gap in Chemical Status Regulation}

The Danish choice of assigning very few recipients the label of "artificial" or "heavily modified" is ambitious and, from an environmental perspective, applaudable, but it also means that the possibility of arguing the proportionality principle (i.e., that living up to the objectives may be disproportionately expensive when comparing environmental and socioeconomic needs) is not available at the discharge point level. While some flexibility is built into the more qualitative QEs used in regulating ecological status, the chemical status assessment has an inherently quantitative nature, as it is conducted using specific and absolute EQS limit values that apply to all water bodies (regardless of whether they have been assigned as natural, artificial or heavily modified), and with the "one-out-all-out" principle on top.

Separate stormwater discharges do exert a serious pressure on chemical status in the water environment, but, as the statement from the Danish Nature Agency [85] on how to regulate these discharges circumvents chemical substances completely, the discharge permits are unable to make direct conditions to that effect. Instead, the only available approach is a general evaluation of whether the measures planned by the applicant will be sufficient to satisfy the chemical status objectives, and then grant a permit or dismiss the application based on this. Apart from the contradiction in ensuring compliance with highly specific values through the application of general and broad evaluations, a crucial challenge in the regulatory framework is the missing knowledge of the current chemical status of the recipient, as well as knowledge of the expected stormwater runoff outlet concentrations.

The assessments of ecological and chemical status in the water environment are essential steps in the WFD implementation, but unfortunately the Danish status monitoring is quite patchy. This seems to be a common European problem, as Denmark is far from the only country struggling with achieving 
a good status for surface water bodies or reaching an appropriate spatial coverage and reliability of monitoring [39]. Based on the shortcomings for status assessments, it might not be surprising that the current chemical status is rarely mentioned in the permits (as it is unknown), but the fact that the objective for chemical status is only mentioned in one permit underlines our inaction in regulating towards reaching this objective.

If we start to work with separate stormwater discharges at a more strategic level than at the single outlet point scale (as proposed in Section 5.1), then this would also open a door for making catchment-based business cases of whether it is more feasible to treat a specific chemical pollutant at the discharge point and regulate its emission through a permit, or if there might be an economic incentive to controlling that pollutant at the source, e.g., by introducing general BEPs for the choice of material in building regulations, for weed control in the maintenance regulation of pond areas or for heavy transport mitigation in traffic regulation, etc.

\subsection{The Combined Approach for Managing Separate Stormwater Discharges}

Currently, the regulation of separate stormwater discharges only takes a source-focused approach. The effect-focused half of the combined approach would rely on EQSs (which cannot be referenced in permits for separate stormwater discharges) combined with the assessment of the cumulative effect of all discharges made to the recipient (which does not exist for chemical pollutants) and followed up by monitoring (which is only carried out sporadically). Furthermore, the source-focused approach is only allowed to use two out of the three tools presented in the WFD for making permit conditions: BATs and BEPs, but not ELVs, as long as the separate stormwater is considered "normally polluted".

The permit review showed no real application of BEPs, except for descriptions of maintenance routines in the catchment area or around the chosen BAT. In the first case, the mentioned routine was not a condition for granting the permit, and in the latter case, it can be considered part of the BAT concept. Even though the possibility of making BEP requirements exists, it is not a feasible approach in the context of a single discharge permit, but would make more sense as a general municipal, RB or RBD requirement (this is also touched upon in Section 5.2).

Regarding the application of BAT requirements, the permits showed both a very singular view of what constitutes a BAT as well as a very variable perception of the theoretical performance level of said BAT. Emerging and less conventional technologies, such as rain gardens, bioswales or other nature-based techniques, were not addressed in any of the permits, although these types of techniques are being applied to a large extent [125] in connection with the FD and climate change adaptation strategies. This is well in agreement with the fact that the tool catalogs for the WFD cycles only present WDPs as a possible measure. It could also, to some extent, be rooted in our method for sampling permits, as well as in the fact that we have only reviewed discharge permits, while many of these emerging SCMs might call for an infiltration permit. Regardless, new techniques often have a high barrier to entry, partly due to tradition [30] and partly due to a lack of market validation, as there is a documentation gap in treatment potential with these types of techniques in available guidelines [19]. The conservatism towards introducing new SCM techniques is only furthered by the very complicated road to winning BAT status. The use of detention ponds as a BAT has a very well-documented effect on relieving hydraulic stress in the recipients, and several studies also point to a positive effect on recipient water quality, compared to non-delayed outlets [3]. Regarding the specific treatment performance, however, the picture is less clear. As the governing treatment process is sedimentation, ponds mainly target only pollutants associated with particles, and the final outlet concentration will be highly dependent on the inlet concentration [19]. This makes it crucial to know exactly which pollutant types and levels to expect from the catchment before the chosen solution can be labeled as sufficient for complying with environmental objectives in the recipient [8]. From the permits, we know that this catchment assessment currently only takes place (if at all) using averaged, theoretical values of, e.g., N, P and $\mathrm{COD}$, which makes it hard to distinguish between possible acute and chronic effects in the recipient. Furthermore, the permit review showed that the dimensioning and sizing of the detention capacity 
relies on principles of return periods designed for water quantity considerations, though dimensioning of the wet volume in WDPs comes from water quality considerations [123]. This can probably be equally blamed on the missing tools and guidelines for taking a quality-based approach and the abundance of tools and guidelines for the quantity-based approach. Similar reflections are made by Sage et al. [19] in their international review on stormwater management criteria.

In order to further the use of the combined approach, it would be beneficial on the source side to create BAT standards and formalize the road to achieving BAT status, as well as learn more about the actual BAT performance levels. This need has also been recognized in many other countries [126]. Two things can be drawn from observations on guideline use in the permit review: (1) there is a high implementation degree of guidelines in the regulation practice and (2) the currently available guidelines have some shortcomings for recommendations regarding how to ensure compliance with environmental objectives when issuing discharge permits. This presents another possibility for pooling efforts between the member states to address this issue. One example could be to produce and share BAT documentation, not just at the RB or national level, but also at the international level, e.g., within the ecoregions defined in the WFD. Agreeing on international practices and standards, or at the very least compiling them at international level, would also enable a freer competitive market for when the time comes for putting the planned measures into effect. On the effect side, it is necessary to get a better overview of environmental status and understand the effects of the cumulative recipient load of stormwater discharges. For this, we need to have comprehensive emission inventories, which could also support making the business case for whether to remove a certain type of pollutant at the discharge point or phase it out in the catchment. In fact, because our discharge permit practice is currently not coordinated at the RB level, but rather managed point by point, it is especially important that effect-oriented assessments are made to take the cumulative load into account [93].

\subsection{Coordination of Plans and Measures from the Water Framework Directive and the Floods Directive}

With the current implementation of the directives, there is only a limited opportunity for coordination between the RBMPs and the FRMPs. The coordination of flood risk measures is not required beyond the municipal level, the coordination of measures for separate stormwater management does not take place beyond the municipal or even point scale level and, regarding the management of separate stormwater discharges, no coordination is facilitated beyond the single outlet scale.

Although the planning cycles for the WFD and the FD are, in principle, synchronized, the short window of opportunity for coordination between the management plans effectively means that this can only be carried out in a one-way flow from the WFD RBD level to the FD municipal level. Regardless of the one-way, cross-level coordination window, the permits did demonstrate a high level of flood risk awareness in their widespread use of peak flow control conditions. Furthermore, the approach for BAT dimensioning with return periods and safety factors was clearly inspired by approaches for urban flood risk management. In fact, the overall impression is that flood and erosion were the primary concerns taken in the permits, while water quality concerns were more downplayed. This means that there is both a need for following up on the "borrowed" flood risk approaches to make sure they fit into the discharge permit context that they are now being applied in, and a need for new approaches to push for more water quality awareness in the permit practice.

The bottom-up approach used for FRMP creation in Denmark is quite unusual compared to the FD implementation in other countries [127]. On one hand, it promotes local ownership of the FRMPs and is well suited for coordination with the municipal climate change adaptation plans, thus living up to the requirement for all member states to coordinate FRMPs with the national climate change strategies and measures [39]. On the other hand, the coordination of both flood risk and climate change adaptation measures is not required across municipal borders, although voluntary APSFR collaboration is encouraged.

The Danish WFD implementation takes a classic top-down approach, where policy formulation takes place at the central government level, objectives and measures are defined at the national or RBD 
level and the practical implementation is carried out through municipal planning processes or even at the discharge point scale. However, as separate stormwater discharges are not addressed in the PoMs and hardly mentioned in the RBMPs, there is a strong separation between the central government level and the practical local level [32]. This institutional distance is often referred to as the arm's length principle, and it introduces a fragmentation of responsibilities between national and local regulatory authorities that is also known in other countries [18,19], where the local authority is charged with complying with the environmental objectives but without being provided with the regulatory tools or the knowledge of status and measures that it takes to solve the task. This has led to repetitive calls for actions from the local regulators to the national policy makers, which have been voiced in both national news media or at conferences or network meetings in the water sector. While the intent of this polycentric system that outsources the responsibility from a national to a local level is to promote integration across governance levels and allow for local knowledge to come into play [76], in effect, the absence of a clearly outlined approach creates uncertainties, which both instigate the need for creating local guidelines and translate into gaps and discrepancies in the permits. In their study of the implementation of European water policies, Waylen et al. [71] observed that fragmented systems will often face greater struggles to achieve their goals, and polycentric systems should therefore only be favored where it allows for meaningful stakeholder participation. This is well exemplified by the Danish WFD implementation. Here, the RB committees represent that exact meaningful stakeholder participation with valuable local insights on the topic of improving the physical conditions of the natural water systems, while there is no equivalent for the topic of mitigating impacts from separate stormwater discharges and thus the polycentric system allows for them to be overlooked. In regard to the coordination of measures, this means that, while the management of separate stormwater is addressed at the municipal level through the climate change adaptation plans, the coordination of the separate stormwater discharges is not enabled and the reviewed permits confirmed that it does not take place. As such, the intent of integrated RB management from the WFD is not carried out for separate stormwater discharges, because overviews beyond the single discharge point are rarely created. It is possible, however, to find examples outside of this permit review, where several municipalities with shared responsibility for a hydraulically challenged recipient have teamed up to create an overview. Such joint initiatives are, however, voluntary (comparable to the APSFR) and tend to focus on creating an overview of hydraulic load, rather than water quality issues.

Overall, the current practice directly contradicts the WFD goal of RB-level coordination to accommodate the fact that water does not respect administrative boundaries. To stage better conditions for RB coordination goals, it would be beneficial to insist on including discharges from separate systems in the status monitoring and PoMs for the RBMPs in order to achieve a more complete picture of the pressures on the recipient. An additional step towards better coordination could be to ensure that stormwater management as a whole (whether relating to objectives and measures from the WFD, the FD or the climate change adaptation strategy) takes place at the RB level. We need to start managing separate stormwater discharges at a strategic level, and here there is a good opportunity for member states to learn from each other and share experiences of different top-down and bottom-up strategies and what impediments they have identified when working on enabling the integrated management of stormwater quantity and quality.

\subsection{Perspectives for European Water Policy Beyond the Water Framework Directive}

Though we still have the third and final planning cycle ahead, it would take an impossible sprint finish for all member states to live up to the overall water quality aims of the WFD before 2027. It therefore seems inevitable that we are looking at additional phases towards this goal beyond that deadline [39], and an extension of the RBMP mechanism.

The initial focus of WFD implementation has been on mitigating sources, such as agriculture, industry, outlets from WWTPs, CSOs or direct outlets from sewer systems, but we will never reach a "near-natural state" in the recipients without addressing all the pressures-including those from separate 
stormwater discharges. Currently, neither the WFD nor the FD actually use the words "stormwater" or "pluvial" (flooding). The WFD refers to "drainage" in only two cases: (1) in arguing for designating some surface water bodies as artificial or heavily modified when affected by "water regulation, flood protection or land drainage" and (2) in identifying potential groundwater contamination from the groundwater recharge of polluted "rainwater and run-off diversion through land sealing, artificial recharge, damming or drainage". The latter is the only place where the WFD uses the word "rain", and "precipitation" is only mentioned once as an optional factor for describing river characteristics. The FD never uses either of these words. It would be an important shift in European water policy if we dare to take a step towards mentioning stormwater explicitly, and thus ensuring that the regulation of separate stormwater discharges is addressed at a strategy level through the RBMPs.

\section{Conclusions}

The WFD implementation in Denmark has resulted in a regulatory framework, where environmental impacts of separate stormwater discharges are mentioned as pressures in the RBMPs, but are completely overlooked in the associated PoMs. The responsibility for ensuring that stormwater is discharged in a way that balances the need for draining stormwater from the cities with the need for protecting the natural recipients has been delegated to the local municipal authorities. In this polycentric regulatory system, the local regulators often supplement the centrally produced guidelines for stormwater management with their own municipal guidelines or guidelines borrowed from the adjacent fields of flood management and climate change adaptation. This is undertaken to help ensure adequate scientific backing for their decisions in this cross-disciplinary, multi-objective field. The result is a fragmented regulatory practice with built-in uncertainties, and our review of the conditions and requirements made in the municipal discharge permits shows that discrepancies have been introduced as a consequence. In relation to water quantity, this is mainly evidenced by the different approaches to SCM sizing. In the case of water quality, it is illustrated by the divide between the application of hesitant, general and non-operational requirements (a problem in and of itself) and the use of very detailed and specific BAT requirements, which were made with great variation with respect to the expected treatment performance of the same type of technique. Overall, the permits demonstrated a large emphasis on water quantity management to reduce hydraulic stress, while water quality management was more downplayed and mainly aimed at satisfying objectives for ecological status with objectives for chemical status being largely overlooked. This fits with reviews of guidelines for discharge management internationally.

The reviews conducted in this article point to a series of topics to be addressed at the national level: (1) an exemption from EQS compliance in permit conditions for normally polluted, separate stormwater discharges, combined with the patchy effort for monitoring recipient status, effectively means that we are currently betraying the effect side of the combined approach in the WFD; (2) the focus on nutrients and particles for the regulation of water quality in separate stormwater discharges completely ignores the impacts on chemical status in the recipients; (3) the singular perception of what constitutes a BAT and the great uncertainties surrounding expected BAT performance calls for the standardization of the concept, as well as formalized uncertainty analysis and documentation protocols; (4) integrated river basin management, as intended in the WFD, is currently reduced to coordination through a one-way communication flow between measures serving environmental objectives and measures for flood control or climate adaptation. Meanwhile, for separate stormwater discharges, no overview exists at the RB or RBD levels, as these are instead regulated point by point.

Denmark is a unique example of a combined top-down and bottom-up implementation approach to the WFD and the FD, respectively, and it presents interesting insights for other member states that are in the process of reviewing their implementation strategies here on the brink of the third and final WFD planning cycle before the deadline for achieving good status in all surface and groundwaters. Similarly, it would be highly relevant to look at experiences from other member states in addressing 
the issues mentioned above, and, regarding BAT standardization, there is a great potential in working collaboratively with this topic at an international level, e.g., in the ecoregion community.

With the current pace of improvement, it seems unlikely that the overall aim of the WFD (good ecological and chemical status in all water bodies) can be achieved before 2027. Discussions therefore lie ahead within the framework of the EU WFD about the future of RB planning and further possibilities for extensions to reaching environmental objectives. Here, it is a crucial point to include stormwater management explicitly in future water policies, so that this piece of the puzzle may also be approached at a strategic level, thereby enhancing the foundation for the holistic regulation of discharges and enabling the actual integration of measures with the FD or the national climate change adaptation strategy.

Author Contributions: Conceptualization, D.M.R.J., A.T.H.T., T.L., S.E. and P.S.M.; analysis—regulation, D.M.R.J. and P.S.M.; analysis-permits, D.M.R.J., A.T.H.T. and S.E.; writing—original draft preparation, D.M.R.J.; writing-review and editing, P.S.M., A.T.H.T., S.E. and T.L.; visualization, D.M.R.J. and A.T.H.T.; supervision, S.E. and P.S.M. All authors have read and agreed to the published version of the manuscript.

Funding: This research received no external funding.

Acknowledgments: The idea for the research presented in this article was born in a water quality task force appointed under the Water Pollution Committee (a specialist network hosted by the Danish Society of Engineers, IDA). The authors would like to thank all members of this task force for their input. The authors also wish to thank Luca Vezzaro of DTU Environment for his useful input and comments.

Conflicts of Interest: The authors declare no conflict of interest.

\section{Appendix A}

Table A1. List of acronyms presented in this article.

\begin{tabular}{ll}
\hline Acronym & Full Text \\
\hline APSFR & Areas of Potential Significant Flood Risk \\
BAT & Best Available Technique \\
BEP & Best Environmental Practice \\
BOD5 & 5-day Biological Oxygen Demand \\
COD & Chemical Oxygen Demand \\
CSO & Combined Sewer Overflow \\
DANVA & Danish Water and Wastewater Association \\
DK & Denmark \\
DK1 & RBD: Jutland and Funen \\
DK2 & RBD: Zealand \\
DK3 & RBD: Bornholm \\
DK4 & RBD: International \\
DMU & The former National Environmental Research Institute of Denmark \\
DS & Statistics Denmark \\
ELV & Emission Limit Value \\
EPA & Environmental Protection Agency \\
EQS & Environmental Quality Standard \\
EQSD & Environmental Quality Standards Directive \\
EU & European Union \\
FD & Floods Directive \\
FRMP & Flood Risk Management Plan \\
IDA & The Danish Society of Engineers \\
KL & Local Government Denmark \\
\hline
\end{tabular}


Table A1. Cont.

\begin{tabular}{ll}
\hline Acronym & Full Text \\
\hline N & Nitrogen \\
OECD & Organisation for Economic Co-operation and Development \\
P & Phosphorus \\
PFRA & Preliminary Flood Risk Assessment \\
PoM & Programme of Measures \\
QE & Quality Element \\
RB & River Basin \\
RBD & River Basin District \\
RBMP & River Basin Management Plan \\
SCM & Stormwater Control Measure \\
WFD & Water Framework Directive \\
WPC & Danish Water Pollution Committee \\
WWTP & Wastewater Treatment Plant \\
\hline
\end{tabular}

Table A2. Translation of Danish terms presented in this article.

\begin{tabular}{|c|c|}
\hline Danish Term & English Translation \\
\hline $\begin{array}{l}\text { Almindeligt belastede separate } \\
\text { regnvandsudledninger }\end{array}$ & Normally polluted separate stormwater discharges \\
\hline BaneDanmark & Danish Rail Services \\
\hline Basisanalyse & Baseline analysis \\
\hline Bekendtgørelse & (Danish) Statutory Order \\
\hline Danmarks Miljøundersøgelser (DMU) & $\begin{array}{l}\text { The former National Environmental Research } \\
\text { Institute of Denmark }\end{array}$ \\
\hline Danmarks Statistik & Statistics Denmark \\
\hline Dansk fiskeindeks for søer (DFFS) & Danish fish index for lakes \\
\hline Dansk fiskeindeks for vandløb (DFFVa og DFFVAø) & Danish fish index for rivers \\
\hline Dansk søplanteplanktonindeks (DSPI) & Danish plankton index for lakes \\
\hline Dansk søvandplanteindeks (DSVI) & Danish aquatic plant index for lakes \\
\hline Dansk Vand- og Spildevandsforening (DANVA) & Danish Water and Wastewater Association (DANVA) \\
\hline Dansk vandløbsfaunaindeks (DVFI) & Danish aquatic fauna index for rivers \\
\hline Dansk vandløbsplanteindeks (DVPI) & Danish aquatic plant index for rivers \\
\hline Funktionskrav & Performance requirements \\
\hline Fysiske forhold (i recipienten) & Physical conditions \\
\hline Hovedvandoplande & River basins \\
\hline Indsatsprogram (fra Vandområdeplanerne) & Program of Measures (PoM) \\
\hline Klimatilpasning & Climate change adaptation \\
\hline Kommunal risikostyringsplan for oversvømmelse & Municipal Flood Risk Management Plans (FRMPs) \\
\hline Kommunalbestyrelsen & Municipal local council \\
\hline Kommunernes Landsforening (KL) & Local Government Denmark (KL) \\
\hline Lovbekendtgørelse & Act (Danish Consolidation Act) \\
\hline Miljø- og Fødevareklagenævnet & $\begin{array}{l}\text { Court of Appeal under the Danish Ministry of } \\
\text { Environment and Food }\end{array}$ \\
\hline Miljøbeskyttelsesloven (BEK1218) & (Danish) Environmental Protection Act \\
\hline Miljømål & Environmental objectives \\
\hline Miljømålsloven (LBK119) & (Danish) Environmental Objectives Act \\
\hline Natur- og Miljøklagenævnet & $\begin{array}{l}\text { Court of Appeal under the Danish Ministry of Nature } \\
\text { and Environment }\end{array}$ \\
\hline Oversvømmelsesloven (LBK1085) & (Danish) Flood Act \\
\hline Planperiode & Planning cycle \\
\hline Risikostyringsplaner (på vanddistriktniveau) & Flood Risk Management Plans (FRMPs) \\
\hline Sekretariatskommuner & Secretariat municipalities \\
\hline Skybrud & Cloudburst \\
\hline Spildevandsbekendtgørelsen (BEK1317) & Wastewater Statutory Order \\
\hline Spildevandskomittéen (SVK) & (Danish) Water Pollution Committee \\
\hline
\end{tabular}


Table A2. Cont.

\begin{tabular}{ll}
\hline Danish Term & English Translation \\
\hline Spildevandsvejledningen & Ministerial wastewater guideline \\
Udledningstilladelse & Discharge permit \\
Vandhandleplaner & Municipal action plans for carrying out initiatives \\
& from the RBMPs \\
Vandløb & River \\
Vandområdedistrikter & RB districts \\
Vandområdeplan (for hvert vandområdedistriks i & River Basin Management Plan (RBMP), one for each \\
2015-2021 og 2021-2027) & River Basin District (RBD) \\
Vandplan (for hvert hovedvandopland i 2009-2015) & River Basin Management Plan (RBMP), one for each \\
Vandplanlægningsloven & River Basin (RB) \\
Vandråd & (Danish) Water Planning Act \\
Vejdirektoratet & River Basin Committees \\
Virkemiddelkatalog & Danish Road Directorate \\
\hline
\end{tabular}

\section{References}

1. Walsh, C.J.; Roy, A.H.; Feminella, J.W.; Cottingham, P.D.; Groffman, P.M.; Morgan, R.P., II. The urban stream syndrome: Current knowledge and the search for a cure. J. N. Am. Benthol. Soc. 2005, 24, 706-723. [CrossRef]

2. United Nations-Department of Economic and Social Affairs. World Urbanization Prospects, the 2014 revision. Available online: https://esa.un.org/unpd/wup/CD-ROM/ (accessed on 1 March 2018).

3. Koziel, L.; Juhl, M.; Egemose, S. Effects on biodiversity, physical conditions and sediment in streams receiving stormwater discharge treated and delayed in wet ponds. Limnologica 2019, 75, 11-18. [CrossRef]

4. Christensen, A.M.; Nakajima, F.; Baun, A. Toxicity of water and sediment in a small urban river (Store Vejleå, Denmark). Environ. Pollut. 2006, 144, 621-625. [CrossRef]

5. Lerer, S.; Arnbjerg-Nielsen, K.; Mikkelsen, P. A Mapping of Tools for Informing Water Sensitive Urban Design Planning Decisions-Questions, Aspects and Context Sensitivity. Water 2015, 7, 993-1012. [CrossRef]

6. Furse, M.T.; Hering, D.; Brabec, K.; Buffagni, A.; Sandin, L.; Verdonschot, P.F.M. The ecological status of European rivers: Evaluation and intercalibration of assessment methods. Hydrobiologia 2006, 566, 1-2. [CrossRef]

7. Pedersen, M.L. Physical Habitat Structure in Lowland Streams and Effects of Disturbance. Ph.D. Thesis, Freshwater Biological Laboratory, Faculty of Science, University of Copenhagen, Copenhagen, Denmark, 2003.

8. Eriksson, E.; Ledin, A.; Baun, A.; Lützhøft, H.-C.H.; Mikkelsen, P.S. Stormwater priority pollutants versus surface water quality criteria. ATV Jord og Grundvand 2011, 11, 33-44.

9. IPCC. Climate Change and Land: An IPCC Special Report on Climate Change, Desertification, Land Degradation, Sustainable Land Management, Food Security, and Greenhouse Gas Fluxes in Terrestrial Ecosystems; Shukla, P.R., Skea, J., Calvo Buendia, E., Masson-Delmotte, V., Pörtner, H.-O., Roberts, D., Zhai, P., Slade, R., Connors, S., van Diemen, R., et al., Eds.; In Press.

10. Gregersen, I.B.; Sunyer Pinya, M.A.; Madsen, H.; Funder, S.; Luchner, J.; Rosbjerg, D.; Arnbjerg-Nielsen, K. Past, Present, and Future Variations of Extreme Precipitation in Denmark; DTU Environment: Kgs. Lyngby, Denmark, 2014.

11. Statistics Denmark (Dansk Statistik). Statistisk Årbog 2015; Statistics Denmark: Copenhagen, Denmark, 2015.

12. Statistics Denmark (Dansk Statistik). Statistisk Årbog 2016; Statistics Denmark: Copenhagen, Denmark, 2016.

13. Levin, G.; Normander, B. Arealanvendelse i Danmark Siden Slutningen af 1800-Tallet; Faglig rapport fra DMU nr. 682; Danmarks Miljøundersøgelser, Aarhus Universitet: Aarhus, Denmark, 2008.

14. Organisation for Economic Co-Operation and Development (OECD). Built-Up Area and Built-Up Area Change in Countries and Regions. Available online: https://stats.oecd.org/Index.aspx?DataSetCode=BUILT_UP\# (accessed on 5 December 2019).

15. Göbel, P.; Dierkes, C.; Coldewey, W.G. Storm water runoff concentration matrix for urban areas. J. Contam. Hydrol. 2007, 91, 26-42. [CrossRef]

16. Deletic, A.; Orr, D.W. Pollution Buildup on Road Surfaces. J. Environ. Eng. 2005, 131, 49-59. [CrossRef] 
17. Eriksson, E.; Baun, A.; Mikkelsen, P.S.; Ledin, A. Chemical hazard identification and assessment tool for evaluation of stormwater priority pollutants. Water Sci. Technol. 2005, 51, 47-55. [CrossRef]

18. Roy, A.H.; Wenger, Æ.S.J.; Fletcher, Æ.T.D.; Walsh, Æ.C.J.; Ladson, A.R.; Shuster, Æ.W.D.; Thurston, Æ.H.W.; Brown, R.R. Impediments and Solutions to Sustainable, Watershed-Scale Urban Stormwater Management: Lessons from Australia and the United States. Environ. Manag. 2008, 42, 344-359. [CrossRef]

19. Sage, J.; Berthier, E.; Gromaire, M.C. Stormwater Management Criteria for On-Site Pollution Control: A Comparative Assessment of International Practices. Environ. Manag. 2015, 56, 66-80. [CrossRef] [PubMed]

20. Cools, J.; Banfi, P.; McNeill, A.; Zamparutti, T.; Vaes, G. Assessment of Impact of Storm Water Overflows from Combined Waste Water Collecting Systems on Water Bodies (Including the Marine Environment) in the $28 \mathrm{EU}$ Member States-Final Report for Task 1.3; Milieu Ltd.: Brussels, Belgium, 2016.

21. Mitchell, V.G. Applying integrated urban water management concepts: A review of Australian experience. Environ. Manage. 2006, 37, 589-605. [CrossRef] [PubMed]

22. Thorndahl, S.; Schaarup-jensen, K.; Rasmussen, M.R. On hydraulic and pollution effects of converting combined sewer catchments to separate sewer catchments. Urban Water J. 2015, 12, 120-130. [CrossRef]

23. Brombach, H.; Weiss, G.; Fuchs, S. A new database on urban runoff pollution: Comparison of separate and combined sewer systems. Water Sci. Technol. 2005, 51, 119-128. [CrossRef]

24. Mutzner, L.; Staufer, P.; Ort, C. Model-based screening for critical wet-weather discharges related to micropollutants from urban areas. Water Res. 2016, 104, 547-557. [CrossRef]

25. Fletcher, T.D.; Shuster, W.; Hunt, W.F.; Ashley, R.; Butler, D.; Arthur, S.; Trowsdale, S.; Barraud, S.; Semadeni-Davies, A.; Bertrand-Krajewski, J.L.; et al. SUDS, LID, BMPs, WSUD and more-The evolution and application of terminology surrounding urban drainage. Urban Water J. 2015, 12, 525-542. [CrossRef]

26. European Parliament; Council of the European Union. Directive 2000/60/EC of the European Parliament and of the Council of 23 October 2000 Establishing a Framework for Community Action in the Field of Water Policy; Official Journal of the European Communities: Brussels, Belgium, 2000; pp. 1-73.

27. European Parliament; Council of the European Union. Directive 2007/60/EC of the European Parliament and of the Council of 23 October 2007 on the Assessment and Management of Flood Risks; Official Journal of the European Union: Brussels, Belgium, 2007; pp. 27-34.

28. Comission of the European Communities. White Paper-Adapting to Climate Change: Towards a European Framework for Action; Comission of the European Communities: Brussels, Belgium, 2009.

29. European Environment Agency (EEA). European Waters: Assessment of Status and Pressures 2018; Publications Office of the European Union: Luxembourg, Luxembourg, 2018. [CrossRef]

30. Koziel, L. Effects of Stormwater Discharge on the Environment Depending on the Runoff Type Treatment Method and Cost-Effectiveness. Ph.D. Thesis, Department of Biology, University of Southern Denmark, Odense, Denmark, 2018.

31. Keessen, A.M.; van Kempen, J.J.H.; van Rijswick, M.; Robbe, J.; Backes, C.W. European river basin districts: Are they swimming in the same implementation pool? J. Environ. Law 2010, 22, 197-221. [CrossRef]

32. Bourblanc, M.; Crabbé, A.; Liefferink, D.; Wiering, M. The marathon of the hare and the tortoise: Implementing the EU Water Framework Directive. J. Environ. Plan. Manag. 2013, 56, 1449-1467. [CrossRef]

33. Danish Environmental Protection Agency (Miljøstyrelsen). Vandløb. Available online: https://mst.dk/natur -vand/natur/national-naturbeskyttelse/naturpleje/naturplejeportalen/naturtyper-og-deres-pleje/vandloeb/ (accessed on 1 May 2020).

34. Frank-Gopolos, T.; Nielsen, L.; Skovmark, B. (Eds.) Punktkilder 2018; Danish Environmental Protection Agency (Miljøstyrelsen): Odense, Denmark, 2019.

35. European Commission. The Fourth Implementation Report of the WFD-A Commission Communication: The Water Framework Directive and the Floods Directive: Actions towards the "Good Status" of EU Water and to Reduce Flood Risks; European Commission: Brussels, Belgium, 2015.

36. European Commission. Second River Basin Management Plans-Member State: Denmark; European Commission: Brussels, Belgium, 2019.

37. European Commission. First Flood Risk Management Plans-Member State: Denmark; European Commission: Brussels, Belgium, 2019.

38. European Union. Links between the Floods Directive and the Water Framework Directive; European Union: Brussels, Belgium, 2014. 
39. European Commission. Report from the Commission to the European Parliament and the Council on the Implementation of the Water Framework Directive (2000/60/EC) and the Floods Directive (2007/60/EC): Second River Basin Management Plans First Flood Risk Management Plans; European Commission: Brussels, Belgium, 2019.

40. Danish Ministry of Environment and Food (Miljø-og Fødevareministeriet). Danish Environmental Protection Act. Bekendtgørelse af lov om Miljøbeskyttelse. LBK nr 1218 af 25 November 2019 (Miljøbeskyttelsesloven); Danish Ministry of Environment and Food: Copenhagen, Denmark, 2019.

41. Danish Ministry of Environment and Food (Miljø-og Fødevareministeriet). Danish Environmental Objectives Act. Bekendtgørelse af lov om Miljømål m.v. for Internationale Naturbeskyttelsesområder (Miljømålsloven). LBK nr 119 af 26/01/2017; Danish Ministry of Environment and Food: Copenhagen, Denmark, 2017.

42. Danish Ministry of Environment and Food (Miljø-og Fødevareministeriet). Danish Statutory Order No. 449. Bekendtgørelse om Indsatsprogrammer for Vandområdedistrikter. BEK nr 449 af 11 April 2019; Danish Ministry of Environment and Food: Copenhagen, Denmark, 2019.

43. Danish Ministry of Environment and Food (Miljø-og Fødevareministeriet). Danish Statutory Order No. 1729. Bekendtgørelse om kommunalbestyrelsens vandhandleplaner. BEK nr 1729 af 16 December 2015; Danish Ministry of Environment and Food: Copenhagen, Denmark, 2015.

44. Danish Ministry of Environment and Food (Miljø-og Fødevareministeriet). Danish Water Planning Act. Bekendtgørelse af lov om Vandplanlægning. LBK nr 126 af 26 January 2017 (Vandplanlægningsloven); Danish Ministry of Environment and Food: Copenhagen, Denmark, 2017.

45. Danish Ministry of Environment and Food (Miljø-og Fødevareministeriet). Danish Statutory Order No. 1625. Bekendtgørelse om Fastlæggelse af Miljømål for Vandløb, Søer, Overgangsvande, Kystvande og Grundvand. BEK nr 1625 af 19 December 2017; Danish Ministry of Environment and Food: Copenhagen, Denmark, 2017.

46. Danish Ministry of Environment and Food (Miljø-og Fødevareministeriet). Danish Statutory Order No. 1317. Bekendtgørelse om Spildevandstilladelser m.v. Efter Miljøbeskyttelseslovens Kapitel 3 og 4 . BEK nr 1317 af 04 December 2019 (Spildevandsbekendtgørelsen); Danish Ministry of Environment and Food: Copenhagen, Denmark, 2019.

47. Danish Ministry of Environment and Food (Miljø-og Fødevareministeriet). Danish Statutory Order No. 1433. Bekendtgørelse om Krav til Udledning af Visse Forurenende Stoffer til Vandløb, Søer, Overgangsvande, Kystvande og Havområder. BEK nr 1433 af 21 September 2017; Danish Ministry of Environment and Food: Copenhagen, Denmark, 2017.

48. Danish Ministry of Environment and Food (Miljø-og Fødevareministeriet). Danish Flood Act. Bekendtgørelse af Lov om Vurdering og Styring af Oversvømmelsesrisikoen fra Vandløb og søer. LBK nr 1085 af 22 September 17 (Oversvømmelsesloven); Danish Ministry of Environment and Food: Copenhagen, Denmark, 2017.

49. Danish Ministry of Environment and Food (Miljø-og Fødevareministeriet). Danish Statutory Order No. 894. Bekendtgørelse om Vurdering og Risikostyring for Oversvømmelser fra Havet, Fjorde Eller Andre Dele af søterritoriet. BEK 894 af 21 June 2016; Danish Ministry of Environment and Food: Copenhagen, Denmark, 2016.

50. Danish Ministry of Environment and Food (Miljø-og Fødevareministeriet). Danish Statutory Order No. 1022. Bekendtgørelse om Miljøkvalitetskrav for Vandområder og Krav til Udledning af Forurenende Stoffer til Vandløb, Søer Eller Havet. BEK nr 1022 af 25 August 2010; Danish Ministry of Environment and Food: Copenhagen, Denmark, 2010.

51. Danish Ministry of Environment and Food (Miljø-og Fødevareministeriet). Danish Statutory Order No. 448. Bekendtgørelse om Miljømål for Overfladevandområder og Grundvandsforekomster. BEK 448 af 11 April 2019; Danish Ministry of Environment and Food: Copenhagen, Denmark, 2019.

52. Danish Environmental Protection Agency (Styrelsen for Vand og Naturforvaltning). Danish River Basin Management Plans (2015-2021); Danish Environmental Protection Agency: Odense, Denmark, 2016.

53. Danish Coastal Authority (Kystdirektoratet). Danish Flood Risk Management Plans (2010-2015); Danish Coastal Authority: Lemvig, Denmark, 2015.

54. Danish Ministry of Environment and Food (Miljø-og Fødevareministeriet). Spildevandsvejledningen; Danish Ministry of Environment and Food: Copenhagen, Denmark, 2018.

55. Danish Environmental Protection Agency (Miljøstyrelsen). Enhedsomkostninger og Forureningsbegrænsning ved Forskellige Miljøforanstaltninger Enhedsomkostninger og Forureningsbegrænsning ved Forskellige Miljøforanstaltninger; Danish Environmental Protection Agency: Odense, Denmark, 2006.

56. Danish Nature Agency (By-og Landskabsstyrelsen). Retningslinjer for Udarbejdelse af Indsatsprogrammer; Danish Nature Agency: Randbøl, Denmark, 2010. 
57. Danish Nature Agency (Naturstyrelsen). Retningslinjer for Udarbejdelse af Indsatsprogrammer; Danish Nature Agency: Randbøl, Denmark, 2012.

58. Danish Nature Agency (By-og Landskabsstyrelsen). Virkemiddelkatalog_Til Brug for Vandplanindsatsprogrammer for: Overfladevand, Grundvand, Sø-og Vandløbsrestaurering, Spildevand, Regnvand, Dambrug; Danish Nature Agency: Randbøl, Denmark, 2010.

59. Danish Environmental Protection Agency (Styrelsen for Vand og Naturforvaltning). Vejledning til Bekendtgørelse om Indsatsprogrammer for Vandområdedistrikter; Danish Environmental Protection Agency: Odense, Denmark, 2017.

60. Danish Business Authority (Erhversstyrelsen). Vejledning i Planlægning for Forebyggelse af Oversvømmelse og Erosion; Danish Business Authority: Copenhagen, Denmark, 2019.

61. Danish Nature Agency (Naturstyrelsen). Klimatilpasningsplaner og Klimalokalplaner; Danish Nature Agency: Randbøl, Denmark, 2013.

62. Danish Environmental Protection Agency (Styrelsen for Vand og Naturforvaltning). Retningslinjer for Udarbejdelse af Vandområdeplaner 2015-2021: Intern Arbejdsinstruks; Danish Environmental Protection: Odense, Denmark, 2016.

63. Danish Nature Agency (Naturstyrelsen). Danish River Basin Management Plans (2009-2015); Danish Nature Agency: Randbøl, Denmark, 2011.

64. Danish Environmental Protection Agency (Miljøstyrelsen). Vandplanerne 2009-2015; Danish Environmental Protection Agency: Odense, Denmark, 2011.

65. Danish Ministry of Environment and Food (Miljø-og Fødevareministeriet). Arbejdsprogram for Vandområdeplanerne 2021-2027; Danish Ministry of Environment and Food: Copenhagen, Denmark, 2019.

66. Danish Environmental Protection Agency (Miljøstyrelsen). Basisanalyse For Vandområdeplaner 2015-2021; Danish Environmental Protection Agency: Odense, Denmark, 2019.

67. Danish Coastal Authority (Kystdirektoratet). Plantrin 2 Kortlægning af Fare og Risiko for Oversvømmelse. Available online: https://oversvommelse.kyst.dk/planperiode-2016-2021/plantrin-2/ (accessed on 6 April 2020).

68. Danish Nature Agency (Naturstyrelsen). Vejledning til Udarbejdelse af Risikostyringsplaner for Oversvømmelse; Danish Nature Agency: Randbøl, Denmark, 2014.

69. Danish Coastal Authority (Kystdirektoratet). Revurdering og Ajourføring af Risikoområder for Oversvømmelse fra hav og Vandløb; Danish Coastal Authority: Lemvig, Denmark, 2018.

70. Danish Coastal Authority (Kystdirektoratet). Sådan Laver I en Risikostyringsplan; Danish Coastal Authority: Lemvig, Denmark, 2020.

71. Waylen, K.A.; Blackstock, K.L.; Tindale, S.J.; Juárez-Bourke, A. Governing integration: Insights from integrating implementation of European water policies. Water 2019, 11, 598. [CrossRef]

72. Giakoumis, T.; Voulvoulis, N. The Transition of EU Water Policy Towards the Water Framework Directive's Integrated River Basin Management Paradigm. Environ. Manag. 2018, 62, 819-831. [CrossRef] [PubMed]

73. Boeuf, B.; Fritsch, O. Studying the implementation of the water framework directive in Europe: A meta-analysis of 89 journal articles. Ecol. Soc. 2016, 21. [CrossRef]

74. Swedish Agency for Marine and Water Management. Challenges and Good Practice in Implementing the Water Framework Directive in the Nordic Countries; Swedish Agency for Marine and Water Management: Göteborg, Sweden, 2015.

75. Liefferink, D.; Wiering, M.; Uitenboogaart, Y. The EU Water Framework Directive: A multi-dimensional analysis of implementation and domestic impact. Land Use Policy 2011, 28, 712-722. [CrossRef]

76. Nielsen, H.Ø.; Frederiksen, P.; Saarikoski, H.; Rytkönen, A.M.; Pedersen, A.B. How different institutional arrangements promote integrated river basin management. Evidence from the Baltic Sea Region. Land Use Policy 2013, 30, 437-445. [CrossRef]

77. Baaner, L. Lokal Nedsivning og Udledning af Regnvand-Miljømål og Miljøkvalitetskrav; IFRO Rapport; Institut for Fødevare-og Ressourceøkonomi, Københavns Universitet: Copenhagen, Denmark, 2013.

78. Danish Water and Wastewater Association (DANVA); Government Denmark (KL). Administrationspraksis for Regnvandsbassiner og Udledningstilladelser; DANVA: Skanderborg, Denmark, 2018.

79. Water Pollution Committee (Spildevandskomittéen). Skrift nr. 27-Funktionspraksis for Afløbssystemer Under Regn; Water Pollution Committee: Copenhagen, Denmark, 2005.

80. Water Pollution Committee (Spildevandskomittéen). Skrift nr. 30-Opdaterede Klimafaktorer og Dimensionsgivende Regnintensiteter; Water Pollution Committee: Copenhagen, Denmark, 2014. 
81. Water Pollution Committee (Spildevandskomittéen). Skrift nr. 31-Metoder til Bestemmelse af Serviceniveau for Regnvand på Terræn; Water Pollution Committee: Copenhagen, Denmark, 2017.

82. Water Pollution Committee (Spildevandskomittéen). Skrift nr. 29: Forventede ændringer i Ekstremregn Som Følge af Klimaændringer; Water Pollution Committee: Copenhagen, Denmark, 2008.

83. Danish Water and Wastewater Association (DANVA). Designguide for Regnvandsbassiner; DANVA: Skanderborg, Denmark, 2018.

84. Court of Appeal under the Danish Ministry of Nature and Environment (Natur-og Miljøklagenævnet). Afgørelse $i$ sag om Tilladelse til Udledning af Overfladevand til Vandløbet Byåen (NMK-10-00590); Court of Appeal under the Danish Ministry of Nature and Environment: Viborg, Denmark, 2013.

85. Court of Appeal under the Danish Ministry of Nature and Environment (Natur-og Miljøklagenævnet). Afgørelse i Sag om Udledningstilladelse til Udledning af Overfladevand til Køge Bugt (NMK-10-00107); Court of Appeal under the Danish Ministry of Nature and Environment: Viborg, Denmark, 2012.

86. Court of Appeal under the Danish Ministry of Environment and Food (Miljø-og Fødevareklagenævnet). Ophrvelse af Tilladelse og Hjemvisning af Sag om Udledning af Tag-og Overfladevand $i$ Guldborgsund Kommune (NMK-10-01223); Court of Appeal under the Danish Ministry of Environment and Food: Viborg, Denmark, 2018.

87. Banestyrelsen. BN3-12-2: Vejledning til Miljø-og Vandløbssager i Forbindelse Med Afvandingsanlæg; Banestyrelsen: Copenhagen, Denmark, 2003.

88. Banestyrelsen. BN1-11-1: Afvanding af Sporarealer; Banestyrelsen: Copenhagen, Denmark, 2006.

89. Mark, O.; Jensen, N.A.; Dørge, J.; Napstjert, L.; Arnbjerrg-Nielsen, K.; Christiansen, H.; Larsen, T.; Poulsen, P.; Lausten, A.; Nielsen, M.D.; et al. Udledningskrav for Regnbetingede Udløb; Water Pollution Committee: Copenhagen, Denmark, 2002.

90. Johansen, N.B.; Hvitved-Jacobsen, T. Lokal Rensning af Regnvand. Spildevandsforskning fra Miljøstyrelsen, Nr. 49; Danish Environmental Protection Agency: Odense, Denmark, 1992.

91. European Parliament; Council of the European Union. Directive 2008/105/EC of the European Parliament and of the Council of 16 December 2008 on Environmental Quality Standards in the Field of Water Policy, Amending and Subsequently Repealing Council Directives 82/176/EEC, 83/513/EEC, 84/156/EEC, 84/491/EEC, 86/280/EEC and Amending Directive 2000/60/EC of the European Parliament and of the Council; Official Journal of the European Union: Brussels, Belgium, 2008; pp. 84-97.

92. European Comission. Introduction to the EU Water Framework Directive. Available online: https://ec.eur opa.eu/environment/water/water-framework/info/intro_en.htm (accessed on 15 December 2019).

93. Gabriel, O.; Zessner, M. Discussion of an environment quality standard based assessment procedure for permitting discharge. Water Sci. Technol. 2006, 54, 119-127. [CrossRef]

94. Jirka, G.H.; Bleninger, T.; Leonard, D.; Hauschild, I. Umweltqualitätsnormen in der EG-WasserrahmenrichtlinieSinnvolles oder lästiges Attribut für Gewässergütemanagement? KA-Abwasser Abfall 2003, 50, 350-357.

95. European Environment Agency (EEA). Disasters in Europe: More Frequent and Causing More Damage. Available online: https://www.eea.europa.eu/highlights/natural-hazards-and-technological-accidents (accessed on 5 April 2020).

96. European Comission. The EU Floods Directive. Available online: https://ec.europa.eu/environment/water/f lood_risk/ (accessed on 12 January 2020).

97. Danish Government (Regeringen). Regeringsgrundlag_et Danmark der Står Sammen; Danish Government: Copenhagen, Denmark, 2011.

98. Danish Environmental Protection Agency (Miljøstyrelsen). Kilder til Spildevandsudledning. Available online: https://mst.dk/natur-vand/vand-i-hverdagen/spildevand/kilder-til-spildevandsudledning/ (accessed on 9 April 2020).

99. Danish Nature Agency (Naturstyrelsen). Virkemidelkatalog-Til brug for Vandplanernes Indsatsprogram for: Overfladevand, Grundvand, Sø-og Vandløbsrestaurering, Spildevand, Regnvand, Dambrug; Danish Nature Agency: Randbøl, Denmark, undated.

100. Eriksen, J.; Jensen, P.N.; Jacobsen, B.H. (Eds.) Virkemidler til Realisering af 2. Generations Vandplaner og Målrettet Arealregulering; DCA-Danish Centre For Food And Agriculture, Aarhus University: Aarhus, Denmark, 2014.

101. COWI. Virkemidler Overfor Punktkilder; Danish Environmental Protection Agency: Odense, Denmark, 2014. 
102. Kristensen, E.A.; Niels, J.; Jan, N.; Anders, K. Virkemidler til Forbedring af de Fysiske Forhold $i$ Vandløb; DCE-Danish Centre For Environment And Energy, Aarhus University: Aarhus, Denmark, 2019.

103. COWI. Virkemidler over for Punktkilder; Danish Environmental Protection Agency: Odense, Denmark, 2019.

104. Danish Government (Regeringen). Sådan Håndterer vi Skybrud og Regnvand; Danish Government: Copenhagen, Denmark, 2012.

105. Danish Environmental Protection Agency (Miljøstyrelsen). Klimatilpasning. Available online: https://www. klimatilpasning.dk/ (accessed on 8 April 2020).

106. Danish Standards (Dansk Standard). DS/EN 752:2017; Danish Standards: Copenhagen, Denmark, 2017.

107. Danish Water and Wastewater Association (DANVA). Vejledninger og Rapporter. Available online: https: //www.danva.dk/publikationer/vejledninger-og-rapporter/ (accessed on 8 April 2020).

108. Danish Environmental Protection Agency (Miljøstyrelsen). Partnerskaber og Netværk. Available online: https://www.klimatilpasning.dk/kommuner/partnerskaber-og-netvaerk/ (accessed on 8 April 2020).

109. Vand i Byer. Kvalitet af Regnafstrømning. Available online: http://regnvandskvalitet-abc.teknologisk.dk/ (accessed on 8 April 2020).

110. Vand i Byer. ViB—Regn med Kvalitet (IP10); Danish Agency for Science and Higher Education: Copenhagen, Denmark, 2014.

111. Byer i Vandbalance. Vurdering af Regnafstrømningens Kvalitet før og Efter Rensning; Byer i Vandbalance: Taastrup, Denmark, 2015.

112. Vezzaro, L.; Brudler, S.; Mcknight, U.S.; Rasmussen, J.J.; Mikkelsen, P.S.; Arnbjerg-Nielsen, K. Operationelle Udlederkrav for Regnbetingede Overløb fra Faellessystemer til Vandløb; DTU Environment: Kgs. Lyngby, Denmark, 2017.

113. Aarhus Kommune; Aarhus Vand A/S. Regnvandsbassiner-Design og Dimensionering; Aarhus Kommune: Aarhus, Denmark, 2016.

114. Larsen, T.H.; Vollertsen, J.; Gabriel, S. Risiko ved Nedsivning og Udledning af Separatkloakeret Regnvand; Aalborg University: Aalborg, Denmark, 2012.

115. Vand i Byer. Kommunale Procedurer for Tilladelser (Collection of Municipal Procedures for Issuance of Permits). Available online: http://regnvandskvalitet-abc.teknologisk.dk/kommunal-praksis-lovgivning/kom munale-procedurer-for-tilladelser/ (accessed on 27 September 2019).

116. Danish Road Directorate (Vejdirektoratet). Vejregelrådet Håndbog Afvandingskonstruktioner-Trug Og Grøfter; Danish Road Directorate: Copenhagen, Denmark, 2017.

117. Danish Road Directorate (Vejdirektoratet). Vejregelrådet Håndbog Afvandingskonstruktioner—Bassiner; Danish Road Directorate: Copenhagen, Denmark, 2015.

118. Danish Road Directorate (Vejdirektoratet). Vejregelrådet Vejkonstruktioner, Afvandingskonstruktioner; Danish Road Directorate: Copenhagen, Denmark, 2009.

119. Hovedstadens Udviklingsråd. Regionplan 2005 for Hovedstadsregionen, Visioner og Hovedstruktur; Hovedstadens Udviklingsråd: Copenhagen, Denmark, 2005.

120. Court of Appeal under the Danish Ministry of Nature and Environment (Natur-og Miljøklagenævnet). Afgørelse i sag om Tilladelse til Udledning af Vejvand til Vandløbene Hulbækken/Karlslundebækken og Møllebækken (NMK-10-00573); Court of Appeal under the Danish Ministry of Nature and Environment: Viborg, Denmark, 2015.

121. Klikovand. Vilkår til Udledning af Overfladevand fra Klimatilpasningsprojekter til Natur-Samling af Vilkår fra 14 Udledningstilladelser; Klikovand: Taastrup, Denmark, 2017.

122. Vezzaro, L.; Arildsen, A.L.; Johansen, N.B.; Arnbjerg-Nielsen, K.; Mikkelsen, P.S. Uncertainty Analysis of Model-Based Calculations of Wet-Weather Discharges from Point Sources; DTU Environment: Kgs. Lyngby, Denmark, 2019.

123. Vollertsen, J.; Hvitved-Jacobsen, T.; Nielsen, A.H. Faktablad om Dimensionering af våde Regnvandsbassiner; Aalborg University: Aalborg, Denmark, 2012.

124. Brudler, S.; Rygaard, M.; Arnbjerg-Nielsen, K.; Hauschild, M.Z.; Ammitsøe, C.; Vezzaro, L. Pollution levels of stormwater discharges and resulting environmental impacts. Sci. Total Environ. 2019, 663, 754-763. [CrossRef]

125. City of Copenhagen (Københavns Kommune). Klimatilpasningsredegørelsen 2018 (Udkast); City of Copenhagen: Copenhagen, Denmark, 2018. 
126. Lucke, T.; Nichols, P.; Shaver, E.; Lenhart, J.; Welker, A.; Huber, M. Pathways for the Evaluation of Stormwater Quality Improvement Devices-The Experience of Six Countries. Clean Soil Air Water 2017, 45. [CrossRef]

127. Andersen, K.J. Nyt om Oversvømmelsesdirektivet-Nr. 4 December 2019; Danish Coastal Authority: Lemvig, Denmark, 2019.

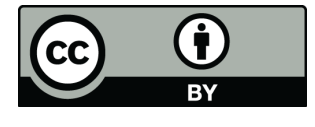

(C) 2020 by the authors. Licensee MDPI, Basel, Switzerland. This article is an open access article distributed under the terms and conditions of the Creative Commons Attribution (CC BY) license (http://creativecommons.org/licenses/by/4.0/). 